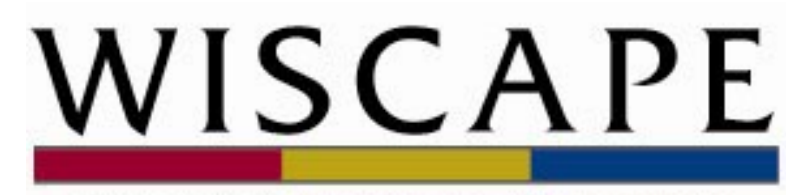

Wisconsin Center for the Advancement

of Postsecondary Education

\title{
The Impact of New College Graduates on Intrastate Labor Markets
}

Philip A. Trostel

University of Maine

July 2007

\author{
Address Correspondence to: \\ Philip A. Trostel \\ Department of Economics \\ University of Maine \\ 5715 Coburn Hall \\ Orono, ME 04469-5715 \\ Phone: (207) 581-1651 \\ E-mail: philip.trostel@maine.edu
}




\begin{abstract}
A crucial issue in the debate on state support for higher education is the extent that a state's production of college graduates affects the state's education attainment. The view that many new graduates take their state-supported degrees to labor markets in other states undermines states' incentives to promote wider access to college. This study offers reasons to be skeptical of this view, and develops a simple framework to quantify the intrastate labor-market effects from the production of new college graduates. Data from the Integrated Postsecondary Education Data System and the Current Population Survey are used to quantify the effects of new graduates on states' net migration, employment, unemployment, labor force nonparticipation, and wages of college graduates. The results indicate that a state's production of college graduates has a nearly proportionate impact on the state's college attainment.
\end{abstract}

\author{
About the Author \\ Philip A. Trostel is professor in the Department of Economics and the Margaret Chase \\ Smith Center for Public Policy at the University of Maine. He is also a WISCAPE faculty \\ affiliate. Among other things, his research examines how fiscal policies affect the incentives to \\ invest in education and training. His research also explores the quantitative effects of education \\ on wages and employment, as well as the implications for economic growth. For more \\ information, please visit: http://www.umaine.edu/economics/Faculty/Trostel.htm.
}




\section{Introduction}

Public investment in higher education is a falling priority. Shares of state government budgets devoted to public higher education have shrunk dramatically in recent decades. In fiscal year 1984, nationwide net state funding for higher education was 4.1 percent of total state government spending (derived from data from the U.S. Census Bureau's State and Local Government Finances). In 1994, this proportion was 2.4 percent. In 2004, this percentage had decreased further to 1.8 percent. Naturally this has led to a great deal of concern and criticism from advocates of public higher education. ${ }^{1}$ Many involved in public higher education perceive the relative decline in state support for higher education as misguided, not only for the institutions and their students, but for the states as a whole. Many outside of public higher education (such as state legislators) evidently disagree. State tax dollars have valuable uses elsewhere, such as staying in taxpayers' pockets. This issue eventually boils down to whether public support for higher education is a good investment of state tax dollars. Although higher education is clearly a good investment for individuals on average, ${ }^{2}$ this does not necessarily make it a good investment for states.

This study attempts to shed light on an important part of this issue. A concern frequently expressed in the debate on state support for higher education is that many graduates from public universities subsequently settle in other states. Indeed, interstate mobility generally increases with education attainment. ${ }^{3}$ College graduation does not necessarily create a corresponding

\footnotetext{
${ }^{1}$ See, for example, Hovey (1999), Cunningham, Wellman, Clinedinst, and Merisotis (2001), and National Center for Public Policy and Higher Education (2003).

${ }^{2}$ Literally hundreds of studies have confirmed that a healthy economic rate of return to higher education. Recent U.S. estimates indicate an average rate of return of close to 10 percent. For surveys of this literature see Ashenfelter, Harmon, and Oosterbeek (1999) and Card (1999).

${ }^{3}$ For example, see Long (1988), Bound and Holzer (2000), Kodrzycki (2001), and Schachter (2001).
} 
increase in the state's education attainment. ${ }^{4}$ This undermines incentives for states to support higher education. ${ }^{5}$ State policymakers often express an aversion to using public funding of higher education to subsidize the workforce development of other states.

Another way of expressing this concern is that there may not be enough appropriate jobs in a state to employ all of the new college graduates. Hence, an increase in the numbers of graduates in a state would only hasten the departure of state-financed degrees. This is just basic supply and demand. If the supply of college graduates increases, then there will be greater unemployment among college graduates, which will create downward pressure on wages, and hence lead to out migration of college graduates. This is essentially the concern voiced in the well-known 1976 book The Overeducated American by Richard Freeman.

Contrary to the dire predictions in the 1970s, the return to higher education did not fall as more Americans obtained college degrees. In fact, the economic return to higher education rose in the 1980s and early 1990s. ${ }^{6}$ The demand for college-educated labor evidently grew faster than the supply. Indeed, this phenomenon sparked considerable research. The widening income gap between the more- and less-educated is generally attributed to technological progress and increasing international trade. The suggestion in this literature is that these events are exogenous, that is, unrelated to the increases in the numbers of college graduates.

An alternative hypothesis is that the changes in the demand for skilled labor are largely an endogenous response to the rising numbers of workers with degrees. That is, the supply of college-educated labor essentially creates its own demand. This is a variation on the theme known as Say's Law. The demand for different types of labor is not fixed; i.e., the number of

\footnotetext{
${ }^{4}$ Indeed, Groen (2004) and Bound, Groen, Kézdi, and Turner (2004) present evidence suggesting a weak relationship between states' college graduation and college attainment.

${ }^{5}$ On this issue, see Strathman (1994), Justman and Thisse (1997), and Wildasin (2000).
} 
jobs is not fixed. Jobs are created. Moreover, job creation is not random; the jobs that are created are those that best match the skills of the workforce. This hypothesis runs contrary to the pervasive popular view of jobs. We observe jobs being lost to technological change and to foreign countries, but we have a hard time imagining what jobs will emerge to replace them. The "lump of labor fallacy" is pervasive, despite the record of countless jobs being created (and destroyed) over the decades.

After a little thought, though, it seems pretty clear that the creation of jobs is not random. Job creation within a region is a function of the region's workforce. For example, if one wants to start a firm that needs low-skilled labor, there is an obvious incentive to place it in a low-wage region. If one wants to start a firm that needs rocket scientists, there is an obvious incentive to locate where one can most easily attract top rocket scientists. Where particular jobs are created largely depends on the skills possessed by the local workforce. Similarly, the adoption of new technologies depends on the nature of the local workforce. Attracting educated workers from away is costly. Hence, it is no coincidence that high-tech clusters, such as Silicon Valley and the Research Triangle, are located near important universities. Although those with more education tend to migrate toward higher-paying regions, it is equally if not more true that high-wage jobs move toward regions with higher-skilled workers. In other words, a highly educated workforce to some extent attracts and creates its own jobs.

\section{Conceptual Framework}

Practically every large state university in the country tracks the migration of its recent graduates to some extent. Numerous studies document the extent that college graduates remain

\footnotetext{
${ }^{6}$ For a surveys of this literature, see Levy and Murname (1992) and Katz and Autor (1999).
} 
in the state. ${ }^{7}$ Although this provides some information on the impact of new graduates on a state's labor market, this sort of evidence is not sufficient. What really matters is not emigration (or lack thereof), but net migration. It is the net leakage of college graduates (among other things) that matters for judging states' interests in supporting higher education. ${ }^{8}$ Interstate migration occurs for various reasons, so there will always be some emigration of labor. To focus on the gross emigration of a state's college graduates mixes these reasons with the specific effect of new graduates on the state's labor market. Moreover, workers and jobs are not homogenous (especially in instances of high skills), thus job matching is an important aspect of labor markets. The lowest rate of emigration of college-educated labor is not necessarily desirable. What is desirable from a state's economic perspective is the thickening of the labor markets for various types of educated labor. A state with a thick supply of highly skilled workers has a significant competitive advantage in attracting and creating high-wage jobs. Hence, it is the net impact of new college graduates on intrastate labor markets that is the relevant issue.

The starting point for the conceptual model is the identity:

$$
S_{\mathrm{m}, \mathrm{s}, \mathrm{t}}-D_{\mathrm{m}, \mathrm{s}, \mathrm{t}} \equiv X_{\mathrm{m}, \mathrm{s}, \mathrm{t}}
$$

where $S_{\mathrm{m}, \mathrm{s}, \mathrm{t}}$ is the supply of labor in market $m$ in state $s$ in year $t, D$ is the demand for labor, and $X$ is the excess supply of labor. Public support for higher education is predominately at the state level, thus states are the natural geographic unit for this analysis. Labor market $m$ could be the market for holders of bachelor's degrees, for example.

\footnotetext{
${ }^{7}$ Some recent examples are Tornatzky, Gray, Tarant, and Howe (1998), Tornatzky, Gray, Tarant, and Zimmer (2001), Kodrzycki (2001), Sanderson and Dugoni (2002), Groen (2004), Parsad and Gray (2005), and Gottlieb and Joseph (2006).

${ }^{8}$ Bound, Groen, Kézdi, and Turner (2004) is the only study that (implicitly) quantifies the net effect of graduates on attainment. Their approach, however, differs from the present one in several dimensions. Most importantly, their approach implicitly allows for migration of non-graduates. Thus, the problem with their approach in the present context is that it is unknown to what extent that their results are driven by net emigration of those with college
} 
Differentiating equation (1) gives:

$$
\Delta S_{\mathrm{m}, \mathrm{s}, \mathrm{t}}-\Delta D_{\mathrm{m}, \mathrm{s}, \mathrm{t}}=\Delta X_{\mathrm{m}, \mathrm{s}, \mathrm{t}}
$$

The change in the supply of college graduates is:

$$
\Delta S_{\mathrm{m}, \mathrm{s}, \mathrm{t}}=G_{\mathrm{m}, \mathrm{s}, \mathrm{t}}-\Delta N_{\mathrm{m}, \mathrm{s}, \mathrm{t}}-M_{\mathrm{m}, \mathrm{s}, \mathrm{t}}
$$

where $G$ is the number of new graduates entering the labor market, $\Delta N$ is the net number of those leaving the labor force, and $M$ is the net interstate out-migration from the labor market.

To empirically implement this model it is assumed that $D_{\mathrm{m}, \mathrm{s}, \mathrm{t}} \equiv E_{\mathrm{m}, \mathrm{s}, \mathrm{t}}$, where $E$ is the number employed, and $X_{\mathrm{m}, \mathrm{s}, \mathrm{t}} \equiv U_{\mathrm{m}, \mathrm{s}, \mathrm{t}}$ where $U$ is the number unemployed. Substituting these assumptions and equation (3) into equation (2) delivers the basic point of this study:

$$
G_{\mathrm{m}, \mathrm{s}, \mathrm{t}}=\Delta E_{\mathrm{m}, \mathrm{s}, \mathrm{t}}+\Delta U_{\mathrm{m}, \mathrm{s}, \mathrm{t}}+\Delta N_{\mathrm{m}, \mathrm{s}, \mathrm{t}}+M_{\mathrm{m}, \mathrm{s}, \mathrm{t}}
$$

New entry into a labor market causes a corresponding increase in employment, unemployment, nonparticipation, or out-migration. The crucial question in this study is what combination of these possibilities is generally observed in the data. That is, $\Delta E_{\mathrm{m}, \mathrm{s}, \mathrm{t}}=\beta_{\mathrm{E}} G_{\mathrm{m}, \mathrm{s}, \mathrm{t}}, \Delta U_{\mathrm{m}, \mathrm{s}, \mathrm{t}}=\beta_{\mathrm{U}} G_{\mathrm{m}, \mathrm{s}, \mathrm{t}}$, $\Delta N_{\mathrm{m}, \mathrm{s}, \mathrm{t}}=\beta_{\mathrm{N}} G_{\mathrm{m}, \mathrm{s}, \mathrm{t}}$, and $M_{\mathrm{m}, \mathrm{s}, \mathrm{t}}=\beta_{\mathrm{M}} G_{\mathrm{m}, \mathrm{s}, \mathrm{t}}$, where $\beta_{\mathrm{E}}+\beta_{\mathrm{U}}+\beta_{\mathrm{N}}+\beta_{\mathrm{M}}=1$. Although the individual $\beta$ fractions must sum to unity, they are not necessarily bounded between zero and one.

Thus, there are four equations to be estimated:

$$
\begin{aligned}
& \Delta E_{\mathrm{m}, \mathrm{s}, \mathrm{t}}=\alpha_{\mathrm{E}}+\beta_{\mathrm{E}} G_{\mathrm{m}, \mathrm{s}, \mathrm{t}}+\varepsilon_{\mathrm{E}} \\
& \Delta U_{\mathrm{m}, \mathrm{s}, \mathrm{t}}=\alpha_{\mathrm{U}}+\beta_{\mathrm{U}} G_{\mathrm{m}, \mathrm{s}, \mathrm{t}}+\varepsilon_{\mathrm{U}} \\
& \Delta N_{\mathrm{m}, \mathrm{s}, \mathrm{t}}=\alpha_{\mathrm{N}}+\beta_{\mathrm{N}} G_{\mathrm{m}, \mathrm{s}, \mathrm{t}}+\varepsilon_{\mathrm{N}} \\
& M_{\mathrm{m}, \mathrm{s}, \mathrm{t}}=\alpha_{\mathrm{M}}+\beta_{\mathrm{M}} G_{\mathrm{m}, \mathrm{s}, \mathrm{t}}+\varepsilon_{\mathrm{M}},
\end{aligned}
$$

where $\varepsilon$ is the unexplained random variation in the dependent variable. The errors in equations (5) - (8) are not independent, thus these equations are estimated simultaneously (i.e., seemingly 
unrelated regressions). Equation (4) dictates the constraints $\beta_{E}+\beta_{U}+\beta_{N}+\beta_{M}=1$ and $\alpha_{E}+\alpha_{U}+$ $\alpha_{N}+\alpha_{M}=0$. The coefficient of the most interest is $\beta_{M}$. If $\beta_{M}$ equals zero, then the production of more college graduates does not hasten their departure to other states.

A slightly simpler way of expressing this is a direct effect of new graduates on the number of graduates in a state, that is, on the state's college attainment:

$$
\Delta A_{\mathrm{m}, \mathrm{s}, \mathrm{t}}=\alpha_{\mathrm{A}}+\beta_{\mathrm{A}} G_{\mathrm{m}, \mathrm{s}, \mathrm{t}}+\varepsilon_{\mathrm{A}}
$$

where $\Delta A$ is the change in the number of degree holders in the state. By construction, $A=E+U$ $+N$. Thus, $\beta_{\mathrm{A}}=\beta_{\mathrm{E}}+\beta_{\mathrm{U}}+\beta_{\mathrm{N}}=1-\beta_{\mathrm{M}}$.

A corroborating, and somewhat simpler, test is the effect of new graduates on wage rates of college graduates:

$$
\Delta W_{\mathrm{m}, \mathrm{s}, \mathrm{t}}=\alpha_{\mathrm{W}}+\beta_{\mathrm{W}} \mathrm{g}_{\mathrm{m}, \mathrm{s}, \mathrm{t}}+\varepsilon_{\mathrm{W}}
$$

where $\Delta W$ is the change in the natural logarithm of the real wage rate, and $\mathrm{g}$ is the rate of flow of new graduates (i.e., the number of new graduates relative to the existing stock of college graduates: $\mathrm{g} \equiv G / A)$. $\beta_{\mathrm{W}}$ measures the percentage change in the real wage rate of college graduates per percentage point rate of new graduate production. If $\beta_{\mathrm{W}}$ equals zero, then producing college graduates attracts the jobs for them (i.e., the demand for college graduates changes at the same rate as the supply).

An important potential problem in the above framework is that entry into a labor market might not be exogenous. The causing variable of interest, $G$, may not be exogenous. Thus, ordinary regression techniques may generate biased estimates of the causal effects of producing college graduates. To be more specific, college students have an incentive to attend a college in 
a state with strong post-graduation job prospects. If the state-of-college choice is correlated with expected employment growth, and if expected employment growth is correlated with actual employment growth, then to at least some extent the flow of new college graduates is following employment growth, rather than the other way around. Thus, $\beta_{\mathrm{E}}$ from an ordinary regression may be an upwardly-biased estimate of the causal effect of $G$ on $E$. To uncover the causal effect of the flow of new graduates, a two-stage instrumental variables approach is appropriate. Fortunately there is a good instrument for $G$. A straightforward instrument for college graduates is the number of high school graduates four years earlier.

\section{Data}

This project uses two public-use datasets: the Integrated Postsecondary Education Data System (IPEDS) from the National Center for Education Statistics (NCES) and the Current Population Survey (CPS) from the Bureau of the Census.

Annual data on the flow of new college-educated labor into each state from are calculated from merging the annual IPEDS Completions and Institutional Characteristics files. These institutional-level data are aggregated into totals for each state. Degrees conferred are sorted into five levels: associate's, bachelor's, master's, professional, and doctorate. Degrees are also separated into those earned from public institutions and private institutions. ${ }^{9}$ From 1995 onwards graduates can be sorted into American residents and nonresidents.

Degrees can also be sorted into different areas of study using IPEDS' CIP (Classification of Instructional Programs) codes. Given the nature of the labor-market data (to be discussed

\footnotetext{
${ }^{9}$ Graduates from Washington, DC are excluded. Graduates from U.S. military colleges are also excluded to be consistent with the labor-market data that do not include military personnel. The number of these graduates is very small (0.6 percent of the total), thus this exclusion has an imperceptible affect on the results.
} 
below), sorting degrees into specific majors is not fruitful. Thus, degrees are sorted into seven broad areas of study: computer, math, life, and physical science (11.2 percent of bachelor's degrees); social science (14.4 percent); engineering (4.8 percent); business (20.9 percent); education (10.6 percent); health professions (6.7 percent); and all other majors (31.4 percent). The placement of the various CIP majors into these categories follows the National Science Foundation's classification of fields.

IPEDS does not separate degrees into those conferred to in-state and out-of-state students. These can be estimated, however. Some years of the IPEDS Enrollment files (to be specific, odd academic years with the exception of 1991) have information on in-state and outof-state incoming freshmen. bachelor's degrees awarded to out-of-state students for each state are estimated by applying the percentage of out-of-state freshmen four years earlier (percentages for missing years are imputed) to the total number of degrees. Obviously there is imprecision in these estimates, but the measurement error is likely to be consistent across states and time.

Annual labor force data by education attainment at the state level are not available. Thus, these data are estimated using individual-level data from the annual CPS Historic Earner Study (formerly known as the Outgoing Rotation Groups). To be specific, this study uses the CPS individual-level data on labor-force status, wages, education attainment, state of residence, interview month, and sampling weight. Calendar-year observations are converted into academic years by assigning observations in the first half of the year to the prior year. For example, an April observation in 1998 is matched against degrees earned in academic year 1997. The underlying assumptions here are that degrees are earned in May, and that the relevant labormarket consequences are for the subsequent year beginning in July. The sample is restricted to those from ages 20 to 70 . 
Numbers of degree holders by labor-force status in each state in each year are estimated by multiplying the sample frequencies times their inverse sampling ratios. Some of the cell sizes are not large (e.g., the sample frequency of holders of doctorates in some small states is only a couple of dozen), hence these estimates are not particularly precise. Thus, these estimates are not sufficiently precise to allow reliable estimation for individual states. Identification of effects is not possible for individual states because there is too much sampling (and business-cycle) variation in the annual labor-market outcomes and too little year-to-year variation in annual number of new graduates. Identification of labor-market effects comes primarily through crossstate variation in the annual number of new graduates. As is shown below, although the estimates of the numbers of degree holders in each labor-force category in each state in each year are imprecise, they appear to have sufficient informational content to allow reliable estimation across states over multiple years.

Log wages are measured as (weighted) mean log weekly earnings for each education group for each state. Obviously wages have grown over time, in both real and nominal terms, and hence are not comparable across years. Thus, weekly wages for each education-state category are made relative to 2006 national-average wages for all education groups. That is, $\mathrm{W}_{\mathrm{m}, \mathrm{s}, \mathrm{t}}=\mathrm{w}_{\mathrm{m}, \mathrm{s}, \mathrm{t}} \times\left(\mathrm{w}_{2006} / \mathrm{w}_{\mathrm{t}}\right)$, where $\mathrm{w}$ is the natural logarithm of nominal wages. In addition to removing nominal wage growth and real wage growth due to technological progress, this removes rising national wages for all education groups due to rising national college attainment (but it allows for wage differences across education groups and across states). Thus, the measure of changing wages is biased downward to some extent. 
Individual-level data on annual interstate migration are from the CPS March Annual Social and Economic Supplement (formerly known as the Annual Demographic File). ${ }^{10}$ This contains both the leaving and entering state of those migrating, thus net migration can be calculated from these data. These March observations are matched against degrees earned in academic year ending in the previous summer. The latest CPS data available at the time of conducting this study is calendar year 2006, hence the last observations of migration correspond to academic year 2005 .

The CPS data obviously do not have observations on those emigrating overseas, but they do have observations on those immigrating from abroad. This causes measured net outmigration to be slightly understated. 0.41 percent of degree holders in the sample immigrated from overseas in the previous year (compared to 3.23 percent moving between states). Thus, to be consistent, foreign immigration is excluded. This makes little difference to the following results, though. Also to be consistent, the (weighted) migration percentages derived from the Annual Social and Economic Supplement are applied to population estimates derived from the Earner Study, which is presumably more precise because they are from much larger samples. Moreover, this puts estimates of all four the dependent variables in equations (5) - (9) on the same basis. However, it should be kept in mind that the migration numbers are derived still from a sample that is considerably smaller than the sample used for the labor-market numbers. Thus, the migration numbers are estimated less precisely than the labor-force-status numbers.

\footnotetext{
${ }^{10}$ Employment, wages, etc. are also available in the Annual Social and Economic Supplement, but the samples in the Historic Earner Study were more than 2.5 larger on average. Moreover, as mentioned above, sample size is an important issue when examining narrowly-defined labor markets (e.g., holders of advanced degrees in small states). Indeed, the very large sample size is the main reason why the CPS is used rather than, say, the National Survey of Recent College Graduates or the National Survey of College Graduates. Many of the cells in these surveys would be inappropriately small.
} 
An important problem in the CPS data is that the measure of college attainment was changed in 1992. Prior to 1992, education attainment was measured as highest year of schooling completed. Moreover, the measure was top-coded at 18 years. Thus, the pre-1992 CPS data do not correspond well with the IPEDS data, particularly for associate's degrees and obviously also for specific advanced degrees. Given this problem in the CPS measure of college attainment, this study relies on the data from 1992 onwards (although potentially a full dataset could be constructed going back to 1985). This yields a dataset of 700 state-year observations.

Finally, data on the number of high school graduates are available from various years of the NCES's Digest of Education Statistics. Unfortunately, data on graduates from private high schools are incomplete. There is an 11-year gap in the estimates of private high graduates from 1981 through 1991, followed by a two-year gap in 1993 and 1994, and single instances of missing information in even years since 1996. Thus, missing observations are imputed using interpolation. Given that slightly less than 10 percent of total high school graduates have been from private high schools since 1981, and that this proportion has been very steady, the measurement error from this interpolation is unlikely to be important.

Tables 1 and 2 provide a summary of the data used in this project. Table 1 summarizes the individual-level data in the CPS during the years emphasized in this study. To be specific, this table shows the average labor-market status by level of college attainment (among the population within the ages of 20 to 70 ). In the following empirical analysis, these proportions are compared to the estimated coefficients.

Table 2 summarizes the data used in the regressions. That is, it shows the average number of degrees awarded in each state in each year (according to the IPEDS data); the average state-year changes in employment, unemployment, nonparticipation in the labor force, and 
weekly earnings; the average state-year net interstate emigration and gross interstate emigration; the average state-year change in college attainment (i.e., $\Delta$ Degrees in CPS); and the average rate of flow of new graduates (i.e., new graduates as measured in IPEDS relative to the existing number of graduates within the ages of 20 through 70 ).

A couple of points about the data shown in Table 2 are worth noting. First, weekly wages are relative to the national average in 2006 , hence there is no wage growth on average. Second, the CPS generally data understate the number of new degrees, which is to be expected for three reasons. One, foreign emigration, although not explicitly measured in the CPS data, is implicit in the college attainment measure. Two, the CPS data cannot measure the number of deaths of degree holders either. ${ }^{11}$ And three, the CPS data only measure the highest degree earned. Thus, someone earning a second master's degree, for example, would not affect the CPS measure of college attainment. Because there is no way to account for emigration of degree holders, deaths of degree holders, and the earning of multiple degrees at the same level, the theoretical result $\beta_{\mathrm{E}}+\beta_{\mathrm{U}}+\beta_{\mathrm{N}}+\beta_{\mathrm{M}}=1$ is not expected to hold in the unconstrained regressions. One would expect the sum of these coefficients to be slightly less than one.

The understatement of new degrees in the CPS is not uniform across degrees, though. Moreover, the magnitudes of the differences between the IPEDS measure of the average number of new degrees and the CPS measure of the average change in degree attainment are surprising. As shown in Table 2, the CPS average annual state change in associate's degrees is 7.9 percent less than the IPEDS average number of new degrees awarded, while for bachelor's, master's, and

\footnotetext{
${ }^{11}$ To give some sense of the probable magnitude of this problem, the number of 70 year-old holders of college degrees exiting the sample each year is 0.70 percent of degree holders within the ages of 20 to 70 . If population shares were constant across ages and college attainment were constant over time, by construction the number of dying degree holders would be 1.96 percent (i.e., 1/51) of degree holders. Given that deaths before age 70 cannot be accounted for, and that college attainment has increased substantially over the past half century, the magnitude of the annual loss of degree holders must be somewhere between these two percentages.
} 
professional degrees the differences are, respectively, 32.4, 27.7, and 20.5 percent. In addition, the CPS average annual state change in doctorate degrees is 61.3 percent more than the IPEDS number of new doctorates. This latter discrepancy is particularly surprising. In addition to being large and the opposite of the expected direction, the discrepancy is even larger when only degrees awarded to permanent residents are included. Unlike the other degrees, a sizable fraction (24.9 percent) of doctorates is to non-permanent residents. The discrepancy suggests substantial net foreign immigration of holders of doctorate degrees. The CPS data on migration, however, indicate a rate of gross foreign immigration of doctorates that is only moderately higher than for the other degrees (the gross rate of foreign in-migration is 0.77 percent for doctorate degrees, compared to 0.40 percent for the other degrees). Another possible partial explanation is some systematic misreporting of education attainment in the CPS. Specifically, it is possible that some holders of professional degrees (such as doctors of medicine and dentistry) report having doctorate degrees. When combining professional and doctorate degrees, the CPS average annual state change in degrees is only 9.7 percent higher than the IPEDS number of new degrees.

\section{The Empirical Intrastate Effects of New Degrees}

Except for perhaps the problematic case of doctorate degrees, the evidence on whether college students graduating in a state leads to a corresponding increase in college attainment in the state appears to be fairly decisive. The effect is nearly proportionate. In other words, supply of college graduates evidently comes close creating its own demand. ${ }^{12}$

\footnotetext{
${ }^{12}$ Actually, it is not necessarily the college graduates directly attracting the jobs the college graduates. The following estimates could be driven to some extent by indirect effects from a college-educated population, such as
} 


\section{Bachelor's Degrees}

The effect of new bachelor's degrees in a state on college attainment in the state appears to be between about 92 and 100 percent. That is, for every 100 students graduating in a state, college attainment in the state increases by 92 or more. Using various estimation methods consistently shows that the effect is at least 94 percent, give or take a few percentage points. On average, states graduating relatively high numbers of college students evidently experience some net loss of graduates, and states graduating relatively low numbers can free ride on those states to some extent, but this effect is small. Indeed, under some plausible econometric specifications the effect on net migration is not statistically different from zero.

Table 3 shows the estimated intrastate labor-market effects of new bachelor's degrees when the coefficients are not constrained by the theoretical restrictions derived earlier. The two columns on the left are estimated using ordinary-least-squares (OLS) regressions (actually seemingly unrelated regressions). The right two columns are estimated using two-stage instrumental variables (IV) regressions (estimated simultaneously as seemingly unrelated regressions in the second stage). As discussed earlier, a potential problem with the OLS estimates is that the entry of college graduates into a state's labor market might not be exogenous. If this is the case, then ordinary regression techniques can generate biased estimates of the causal effects of producing college graduates. Thus, the number of high school graduates in the state four years earlier is used as an instrument for the number of new bachelor's degrees earned in a state. In the case of the change in log earnings, the number of high school graduates four years earlier relative to the population within the ages of 20 to 70 four years earlier was used as an instrument for the relative number of new bachelor's degrees. The second and fourth 
columns in Table 3 show the results when degrees awarded to non-permanent residents are excluded from total degrees (3.2 percent of total bachelor's degrees were awarded to nonpermanent residents). This is consistent with the unavoidable exclusion of foreign migration in the CPS data. Thus, other things equal, this set of results is preferred. But other things are not equal. In particular, three years of data are lost because the resident/nonresident categorization is not available until the 1995 data.

A quick glance at Table 3 reveals that the coefficient estimates are quite similar across these specifications. The first column of Table 3 shows the base case, that is, the explanatory variable is all new bachelor's degrees awarded in each state in each year from 1992 through 2005. Employment of graduates in the state in the following year increases by 0.537 per new graduate. This is significantly less than the average number of college graduates working $(81.4$ percent, shown in Table 1). Unemployment of graduates in the subsequent year decreases by 0.006 per new graduate, but this coefficient is not statistically different from zero. This coefficient is, however, significantly less than the average number of college graduates unemployed (2.2 percent). Nonparticipation in the labor market increases by 0.136 per new graduate. This is again lower than the average among holders of bachelor's degrees (16.3 percent), but the difference is not statistically significant. Net migration of degree holders increases by 0.041 per new graduate, which is essentially the same as the average proportion of graduates moving between states ( 4.0 percent). This suggests that, on net, new college graduates are not significantly more likely to leave a state than existing college graduates. 
The estimated intrastate impact of new bachelor's degrees on wage growth of college graduates is negative, but is very small and not statistically different from zero. ${ }^{13}$ The base-case coefficient estimate of -0.004 indicates that a one percentage point increase in the rate of flow of new college graduates (which would be a whopping 21 percent increase from the sample mean of 0.0473 ) causes weekly wages to decline by 0.004 percent. Even if the effect was the lower extreme of its 95-percent confidence limit (-0.218), the implied elasticity would be only -0.01 . Thus, the statistical insignificance of this coefficient is an indication that the effect is essentially zero, as opposed to being imprecisely estimated.

Figures $1-5$ illustrate the results above. These scatter plots show the data for equations (5) - (8) and (10) in terms of the state averages during the 1992-2005 time period (using state averages obviously makes the scatter plots less cluttered than using all the observations, while illustrating the same general pattern because identification is primarily through the crosssectional variation in the data).

Table 3 also shows the estimated effect of new bachelor's degrees on the gross rates of interstate migration. In the base case, out-migration of college graduates increases by 0.658 per new college graduate, on average. Of course, this does not mean that 66 percent of new graduates leave their college state. Presumably a substantial fraction of this 66 percent is new graduates, but a substantial fraction is also from existing graduates in the state. This result is consistent with the widespread notion (and well-documented empirical evidence) that many

\footnotetext{
${ }^{13}$ This result appears inconsistent with the findings of Card and Lemieux (2001) and Fortin (2006) (and also Bound et al., 2004) that a relative increase in college graduates in a state causes a statistically significant negative effect on the state's college wage premium. But this is not necessarily the case if, as Moretti (2004) shows, college graduates create significant wage spillovers to non-graduates. That is, the negative effect on the college wage premium in Card and Lemieux and Fortin may be largely driven by the positive effect on wages of non-graduates. Moreover, the apparently inconsistent results could be due to those studies imposing the assumption of a constant rate of exogenous growth in the relative demand for college-educated labor. Resolving this apparent inconsistency is a subject for further research.
} 
publicly-financed college graduates move their human capital to other states. What is probably not widely appreciated is the result that in-migration of college graduates increases by 0.617 per new graduate. This result is consistent with the arguments earlier in this study that producing college graduates in a state thickens the supply of college graduates in a state, and hence attracts the work opportunities for those graduates, and perhaps paradoxically, attracts graduates from other states. These two coefficient estimates are also consistent with the argument that job matching and migration are important in the college-graduate labor market.

The last row of Table 3 shows the relative effect of new bachelor's degrees on college attainment in the state. That is, it shows the estimated effect on attainment $\left(\beta_{\mathrm{A}}\right)$ as a percentage of the total effect $\left(\beta_{\mathrm{A}}+\beta_{\mathrm{M}}\right)$. The base case indicates that the within-state effect on attainment is a little over 94 percent. Its 95-percent confidence interval is between 88.8 and 99.5 percent.

The estimated intrastate effect of new graduates on intrastate attainment is slightly stronger when degrees from non-residents are excluded. Indeed, the effect of new resident graduates on attainment is 99.9 percent of the estimated total effect (with a 95-percent confidence interval of 93.8 to 106.0 percent). The estimated effect on net out-migration is essentially zero in this case. When foreign graduates are excluded, the college graduation in a state evidently leads to an almost exactly proportionate increase in college attainment in the state. The effect of new graduates on employment of graduates in the state in the following year is slightly stronger when excluding foreign graduates, but it is still less than the average number of college graduates working. The effect on unemployment of graduates remains essentially zero, but in this case it is only marginally statistically different from the average number of college graduates unemployed. The estimated effects on nonparticipation and wages are roughly the same as in the base case. 
The IV estimates are very similar to the corresponding OLS estimates. Moreover, because of the strength of the instrument, there is little loss in the precision of the estimates. Not surprisingly, the number of high school graduates four years earlier is a very strong instrument for the number of new bachelor's degrees. The correlation coefficient between high school graduates and new bachelor's degrees four years later is 0.972 (and in the case of the change in wages, the correlation coefficient between high school graduates relative to the population and new college degrees relative to the existing stock of college graduates is 0.497$).{ }^{14}$ Such a strong correlation between states' high school graduates and their college graduates four years later suggests little potential for endogeneity bias. Indeed, despite only a very small loss in precision, none of the IV coefficient estimates are statistically different than their OLS counterparts. Surprisingly, the IV estimates show slightly stronger, although not statistically different, intrastate impacts of new graduates on employment and attainment. If anything, the opposite was expected. The IV confidence interval of the effect of all new graduates on within-state college attainment is between 91.4 and 102.4 percent of the total effect. The IV confidence interval in the case of permanent-resident graduates only is from 96.4 to 108.9 percent.

The dataset is a panel, thus it may be necessary to allow for fixed effects. This does not appear to be needed in this case, though. With the exception of the migration variables, the variables are first differenced, thus the fixed effects are removed. This is confirmed in Appendix Table 1 which shows the results when allowing for random fixed effects. The results are almost identical to those in Table 3. The only detectable differences are in the coefficients on the

\footnotetext{
${ }^{14}$ Moreover, there is a failure to reject the exclusion of high school graduates four years earlier from the secondstage regressions. That is, high school graduates four years earlier easily passes both of the standard tests for instrument validity.
} 
migration variables, and these differences are small. ${ }^{15}$ The upper bounds of the 95 -percent confidence intervals of the effect on net migration are 0.100 or below in all four random-effects cases shown in Appendix Table 1. Thus, this complication is not pursued further.

Table 4 shows the intrastate labor-market effects of new bachelor's degrees when the coefficients are bound by the constraints derived from equation (4); that is, $\beta_{\mathrm{E}}+\beta_{\mathrm{U}}+\beta_{\mathrm{N}}+\beta_{\mathrm{M}}=1$ and $\alpha_{E}+\alpha_{U}+\alpha_{N}+\alpha_{M}=0$. Given the measurement error in the dependent variables (as well as there being no way to account for emigration and deaths of degree holders and multiple degrees at the same level), it would be a surprising coincidence for the sum of the coefficient estimates to be one. Thus, it makes more sense to impose the restriction that the estimates on employment, unemployment, nonparticipation, and migration sum to one.

The constrained estimates in Table 4 are consistent with the unconstrained estimates in Table 3. The constrained coefficient estimates are similar to their proportions in the unconstrained cases. For example, of the total unconstrained estimates for all graduates in the base case, 75.8 percent is in employment [i.e., $0.537 /(0.537-0.006+0.136+0.041)],-0.8$ percent is in unemployment, 19.2 percent in is nonparticipation, and 5.8 percent is in net outmigration. These proportions are about the same as their respective constrained estimates of $72.4,-0.0,20.5$, and 7.1 percent. In the case of resident graduates only, the unconstrained proportions are $78.7,-0.2,21.4$, and 0.1 percent, while the respective constrained coefficients are $74.7,0.2,22.5$, and 2.6 percent. The IV unconstrained proportions in Table 3 are similarly similar to their constrained coefficients in Table 4.

Perhaps a surprising result in the results in Tables 3 and 4 is that the marginal effect of new graduates on nonparticipation is evidently a little larger than the average effect, while the

\footnotetext{
${ }^{15}$ This is confirmed in Hausman tests for the presence of fixed effects. The absence of fixed effects is rejected only
} 
marginal effect of new graduates on employment (and unemployment) is evidently a little smaller than the average effect. At first glance, this seems to indicate that the intrastate supply of college-educated labor does not proportionately create its own demand. But this is inconsistent with the practically negligible effects on unemployment, net migration, and wages. There is, however, a plausible explanation for the relatively large impact on nonparticipation. It is likely that new graduates are more likely than the average degree holder among the 20 to 70 year-old population to pursue advanced studies in the following year. That is, the evidence is consistent with idea that the supply of college graduates in a state creates a somewhat disproportionate impact on the state's graduate-student population. ${ }^{16}$

In summary, there is considerable consistency in the estimates across different econometric specifications. The net leakage of new permanent-resident graduates to other states is statistically insignificant in every specification. The net leakage of all new graduates is less than 8 percent in all specifications. In all specifications there are essentially no negative impacts of new bachelor's degrees on the unemployment rate and wages of college graduates. The effect of new graduates on the employment of graduates is somewhat less than proportionate, and the effect on nonparticipation is slightly more than proportionate (presumably because of relatively more entry into advanced studies). Thus, the evidence indicates that, on average, states that produce relatively more college graduates: (net) export only a small fraction of them at most, do not have higher unemployment or lower earnings for degree holders, and have almost proportionately greater college attainment.

in the migration regressions.

${ }^{16}$ While this conjecture may be plausible, the labor-force participation of traditional college-age graduates is not consistent with it. Although employment of holders of bachelor's degrees within the ages of 20 to 23 is about 2.65 


\section{Associate's Degrees}

Tables 5 and 6 show the estimated intrastate effects of new associate's degrees using the same set of econometric specifications as in Tables 3 and 4. The results are generally similar to the effects of new bachelor's degrees. The effect of new two-year degrees in a state on the state's college attainment is again nearly proportionate. The estimation variations consistently show that the effect is at least 94 percent, give or take a few percent.

Table 5 shows the within-state labor-market effects of new associate's degrees when the coefficients are not constrained by the restrictions derived from the theory. Despite a closer match between the number of new degrees in IPEDS and the annual change in degree attainment in the CPS for associate's degrees than for bachelor's degrees, the sum of the first four unstrained coefficients is a little further below one than in the bachelor's-degree case.

The base case (all graduates using OLS) shows that employment of two-year graduates in the state in the following year increases by 0.413 per new graduate, which is substantially less than the average number of two-year graduates working (80.2 percent). The effect on unemployment is not different from zero, but is statistically less than the average number of twoyear graduates unemployed (2.7 percent). Nonparticipation in the labor market increases by 0.178 per associate's graduate, which is roughly the same as the average among holders of associate's degrees (17.1 percent). Net migration of two-year degree holders is essentially unaffected by new degrees, although the point estimate is not statistically different than the average proportion of two-year graduates moving between states ( 2.7 percent). The estimated impact of new associate's degrees on wage growth is positive, although not statistically different from zero. In addition to the reversal of sign in comparison to the case of bachelor's degrees 
(and the opposite of expected sign), the magnitude of the coefficient on earnings growth of degree holders is much larger. The magnitude is still small, though. Taking the coefficient estimate of 0.184 at face value (keeping in mind that it is not statistically different from zero) indicates that a one percentage point increase in the rate of flow of new two-year graduates (which would be a 24 percent increase from the sample mean of 0.0418 ) causes weekly wages to increase by 0.184 percent (i.e., the elasticity is 0.008 ). The effects of new associate's degrees on gross out- and in-migration are much smaller than in the case of bachelor's degrees, which is to be expected given that holders of two-year degrees move between states less frequently than holders of four-year degrees.

The second column in Table 5 shows the results when non-permanent residents are excluded from total degrees. As discussed in the previous section, this case is consistent with the unavoidable exclusion of foreign migration in labor-market data, but three years of the 13 years of data are lost. In any event, the coefficient estimates are basically unchanged when excluding foreign two-year graduates, which is to be expected given that only 2.0 percent of total associate's degrees were awarded to non-permanent residents.

The third and fourth columns in Tables 5 show the results when using the number of high school graduates in the state two years earlier as an instrument for the number of new two-year degrees earned in a state. The instrument is not quite as strong as is the case of four-year degrees, but it is still very highly correlated with the dependent variable. The correlation coefficient between high school graduates and new associate's degrees two years later is 0.93 (the correlation coefficient between high school graduates relative to the population and new 
two-year degrees relative to the existing stock of two-year graduates two years later is 0.23$){ }^{17}$ As in the case of bachelor's degrees, the IV estimates are generally similar to the corresponding OLS estimates. ${ }^{18}$ Unlike in the bachelor's degree case, though, the IV estimate of the intrastate impact of new Associates degrees on net migration is notably larger than the OLS estimate. Nonetheless, the estimated impact of new degrees on net out-migration remains small (3.9 percent for all graduates, and even smaller for permanent-resident graduates).

The theoretical restriction that the first four coefficients sum to unity (along with the constants summing to zero) is imposed on the regressions reported in Table 6. As discussed earlier, it makes more sense to impose the constraint on the coefficients. The constrained estimates for associate's degrees in Table 6 are consistent with the unconstrained estimates in Table 5, as well as with the estimates for bachelor's degrees in Table 4. Of the total unconstrained estimates for all associate's degrees in reported in Table 5, 69.8 percent is in employment, -0.7 percent is in unemployment, 30.1 percent in is nonparticipation, and 0.7 percent is in net out-migration. These are similar to their respective constrained estimates of 71.0, 2.2, 23.3, and 3.4 percent.

Again as in the case of four-year degrees, the marginal effect of new two-year graduates on nonparticipation is evidently larger than the average effect. Thus, it appears that new associate's graduates are more likely than the average associate's graduates among the 20 to 70 year-old population to pursue additional studies in the following year. In other words, the evidence is consistent with two-year graduates in a state creating a disproportionate impact on the state's four-year-student population.

\footnotetext{
${ }^{17}$ As in the case of bachelor's degrees, the exclusion restriction of high school graduates two years earlier from the second-stage regressions fails to be rejected.
} 
Thus, as in the case of bachelor's degrees, there is considerable consistency in the estimates across different econometric methods. The net leakage of new associate's degrees to other states is less than 6 percent in all specifications. In all specifications the estimated effects of new associate's degrees on the unemployment rate and wages of degree holders are statistically insignificant. The effect of new two-year graduates on employment is somewhat less than proportionate, and the effect on nonparticipation is slightly more than proportionate (presumably because of relatively more entry into four-year programs). On average, states that produce relatively more associate's graduates: (net) export only a small fraction of them, do not have higher unemployment or lower earnings for two-year degree holders, and have almost proportionately greater college attainment.

\section{Master's Degrees}

Table 7 shows the intrastate labor-market effects of new master's degrees using OLS. IV results are not reported for advanced degrees (although high school graduates in the state six years earlier performs well as an instrument for new master's degrees earned in a state and the resulting IV estimates are again similar to their OLS counterparts). The results are generally similar to the effects of new bachelor's degrees and new associate's degrees. The effect of new master's degrees in a state on the state's college attainment is again nearly proportionate. Various estimation specifications consistently show that the effect is at least 92 percent, give or take a few percent.

As with the undergraduate degrees, when the parameters are not constrained as dictated by the theory, the impact on employment $(0.444)$ is positive and strongly statistically significant,

\footnotetext{
${ }^{18}$ Also as in the case of bachelor's degrees, controlling for random fixed effects has perceptible effects only on the
} 
but is well below the average number of master's degree holders employed ( 82.9 percent). The estimated effect of new degrees on unemployment of master's graduates $(-0.009)$ is not statistically different from zero, but is significantly less than the average number of master's graduates unemployed (1.9 percent). The unconstrained coefficient on nonparticipation $(0.189)$ is greater than the average among holders of master's degrees (15.3 percent), but the difference is not statistically significant. The unconstrained effect on net out-migration of master's degree holders (4.5 percent) is statistically significant. As in the case of new undergraduate degrees, the estimated impact of new master's degrees on the growth of weekly earnings of master's degrees holders is not statistically different from zero. The estimated effect of new master's degrees on gross out-migration $(0.455)$ is smaller than in the case of bachelor's degrees $(0.658)$, but larger than in the case of associate's degrees (0.364). Similarly, the effect on gross in-migration of master's degrees $(0.410)$ is between the two other cases $(0.617$ and 0.360$)$.

The second column in Table 7 shows the results when master's degrees awarded to nonpermanent residents are excluded. Degrees to foreign students are relatively more common for advanced degrees than undergraduate degrees. Of total master's degrees awarded from 1995 through 2005, 12.6 percent were to non-permanent residents (compared to 2.0 percent for associate's degrees and 3.2 percent for bachelor's degrees). Thus, it is not surprising that excluding degrees to non-permanent residents affects the unconstrained estimates noticeably more than in the undergraduate cases. In particular, the estimated intrastate effects of new master's degrees on employment and attainment are noticeably higher when excluding nonpermanent residents. The estimated intrastate effect on net out-migration is higher too, thus the estimated proportional effect on attainment is roughly the same in both cases $(93.2$ percent 
versus 92.6 percent). Indeed, the constrained estimates in the third and fourth columns are essentially the same.

As in the cases of bachelor's and associate's degrees, imposing the constraint that the intrastate impacts of new master's degrees sum to unity generally raises the coefficient estimates, but implies roughly the same proportionate effects. Of the total unconstrained effect for all master's degrees, 66.4 percent is in employment, compared to constrained estimate of 0.682 . For nonparticipation, the unconstrained percentage is 28.2 , compared to the constrained estimate of 23.2 percent. For net migration the unconstrained proportion is 6.8 percent, versus 7.9 percent in the constrained case. None of these differences are statistically significant.

The estimates of the within-state labor-market effects of master's degrees are also similar to the estimates of bachelor's and associate's degrees in that the marginal effect of new graduates on nonparticipation is evidently larger than the average effect. In the constrained case, the effect of all new master's degrees on nonparticipation is 23.2 percent, while nonparticipation among master's graduates is 15.3 percent. This again suggests that disproportionate numbers of new master's graduates continue with their graduate studies.

In summary, the estimated intrastate labor-market effects of new master's degrees are consistent across econometric specifications, and similar to the evidence on new associate's and bachelor's degrees. The net leakage of new master's degrees to other states appears to be about 7 or 8 percent. New graduates have no detectible effects on the unemployment and wages of those with master's degrees. The effect of new graduates on employment is somewhat less than proportionate, and the effect on nonparticipation is slightly more than proportionate. 


\section{Professional Degrees}

The estimated intrastate effects of new professional degrees are shown in Table 8 . In the CPS sample of those within the ages of 20 to 70 , only 1.4 percent has a professional degree as the highest qualification. Consequently, the labor-market coefficients are estimated noticeably less precisely in the case of professional degrees than in the earlier cases. But the estimated labor-market effects of new professional degrees are generally similar to those from the lower degrees. The effect of new professional degrees in a state on the state's college attainment, although somewhat less precisely estimated, again appears to be close to proportionate. The different estimation specifications show that the effect is at least 97 percent, give or take several percent. Indeed, the estimated intrastate effect of new professional degrees on education attainment is not statistically different from 100 percent.

As shown in Table 8, when the labor-market coefficients for all new professional degrees are not constrained: the estimated intrastate effect on employment is 0.629 ; the effects on unemployment and weekly wages are not statistically different from zero; the effect on nonparticipation is 0.171 ; the estimated impact on education attainment in the state is 0.806 , which is 97.5 percent of the total effect; the effect on net out-migration is 0.021 , which is not statistically different from zero; and the estimated effects on gross out- and in-migration are 0.712 and 0.692 . The estimated effects of professional degrees the gross rates of migration are higher than for the previous degrees, but otherwise the coefficients are similar to the previous unconstrained cases.

The estimated intrastate impacts of new professional degrees on employment and education attainment are considerably lower when excluding professional degrees awarded to non-permanent residents, though. This result is puzzling. Only 2.3 percent of professional 
degrees were awarded to non-residents. However, the coefficients are not estimated precisely.

The seemingly considerable differences between 0.469 and 0.629 for employment and 0.637 and 0.806 for attainment are not statistically significant. Moreover, in proportionate terms, the results are very similar. The intrastate effect of resident degrees on attainment is 99.0 percent of the total, compared to 97.5 percent for all degrees.

As with the previous degrees, imposing the constraint dictated by the theory raises the coefficient estimates, but the estimated constrained effects are essentially the same as the unconstrained proportionate effects. Of the total unconstrained effect of all new professional degrees: 76.1 percent is in employment, compared to 77.3 percent in the constrained case; 20.7 percent is in nonparticipation, compared to the constrained estimate of 18.6 percent; and 2.5 percent is in net out-migration, compared to 3.2 percent in the constrained case. Moreover, the results are roughly the same for all graduates and only resident graduates when the coefficients are constrained.

Also as with the previous degrees, the estimated impact of new professional graduates on nonparticipation in the labor market is slightly more than proportionate and the estimated effect on employment is slightly less than proportionate. Nonparticipation among holders of professional degrees is 11.2 percent, while the marginal effect of new graduates appears to be about 19 percent or more, although it is not estimated with much precision. Employment among holders of professional degrees is 87.7 percent, while the (imprecisely estimated) marginal effect appears to be 77 percent or less. This is a puzzle. It seems unlikely that significantly disproportionate numbers of professional graduates are continuing with their studies.

To summarize, the intrastate labor-market impacts of new professional degrees are generally consistent across econometric specifications and roughly consistent with the intrastate 
impacts of other degrees. The net leakage of new professional degrees to other states is evidently about 3 percent, and is not statistically different from zero. The effects on unemployment and wages of holders of professional degrees are not statistically different from zero. The effect of new professional graduates on employment is somewhat less than proportionate, and the effect on nonparticipation is slightly more than proportionate.

\section{Doctorate Degrees}

The estimated intrastate labor-market effects of new doctorate degrees are presented in Table 9. In the CPS sample within the ages of 20 to 70 , only 1.1 percent has a doctorate degree (and the IPEDS data suggest an even smaller proportion, and especially for permanent residents). Moreover, as discussed earlier, the data on doctorate degrees appears problematic. Thus, the estimated coefficients are especially less precise than for the other degrees. The estimated intrastate labor-market effects for doctoral degrees are roughly similar to those from previous degrees, but there are some notable differences. Perhaps the most important difference is that effect of new doctorate degrees in a state on the state's education attainment appears to be noticeably less than proportionate. The effect of doctorates on attainment is evidently in the range of 76 to 88 percent, and is not precisely estimated. Thus, it appears that states graduating relatively high numbers of doctorate degree may experience a relatively sizable net loss of them to other states.

The immediate difference in the estimated effects of doctorate degrees from those of the earlier degrees is that the unconstrained coefficients are larger. Unlike the estimates for the other degrees, the unconstrained coefficients for doctorates sum to more than unity. The estimated coefficients on employment and attainment are greater than one, although the difference from 
one is not statistically significant. The coefficient on net out-migration is noticeably larger for doctorate degrees than for the other degrees. The coefficients on gross rates of migration, especially emigration, are also the highest for doctorate degrees. The proportionate effect of all new doctorate degrees on within-state attainment is 87.6 percent, which is noticeably lower (and less precisely estimated) than the other degrees. Its 95-percent confidence interval is from 76.2 to 99.0 percent.

When degrees to non-permanent residents are included, doctorates earned in a state have a statistically significant positive effect on earnings of doctorate holders in the state. None of the other degrees have statistically detectable intrastate effects on wage growth. The magnitude of the effect is also much larger than for the other degrees. This unexpected positive effect of doctorate degrees on wages is still economically small (the implied elasticity is 0.03 ).

Nonetheless, the statistically positive effect on wages is puzzling. Perhaps holders of doctorates and/or doctorate education create significant wage externalities. But this is inconsistent with significant effect of new doctorates on net out-migration of doctorates. Moreover, the effect on wage growth is not close to statistical significance when doctorates awarded to non-permanent residents are excluded.

The only coefficients not noticeably different in the case of doctorate degrees are for unemployment and nonparticipation. As with the other degrees, the effect on unemployment of degree holders is not statistically different from zero. The unconstrained estimate on nonparticipation of all new doctorates is comparable to the other degrees, although with a much larger standard error.

Doctorate degrees also differ from the other degrees in that a sizable proportion is awarded to non-permanent residents. Thus, excluding foreign graduates noticeably affects the 
results. As shown in the second column of Table 9, most of the coefficients are higher still when doctorates to non-permanent residents are excluded. But the standard errors also increase, and the coefficients are not statistically different between the two cases (with the exception of the coefficient on gross out-migration). Although the unconstrained coefficients on employment, nonparticipation, attainment, and gross in-migration are higher when excluding foreign doctorates, the coefficients on gross and net out-migration are proportionately higher, thus the proportionate effect on attainment is somewhat lower (81.9 percent compared to 87.6 percent). This result is counterintuitive, but the difference is also not statistically significant.

The estimated effects of new doctorate degrees are broadly similar to those from the other degrees when the labor-market coefficients are constrained to sum to unity. However, compared to the other degrees, the point estimate on net out-migration is somewhat larger and the point estimate on employment is somewhat smaller. The somewhat puzzling finding that the marginal effect on nonparticipation is evidently larger than the average effect (average nonparticipation of doctorates is 11.7 percent) is again found.

The intrastate labor-market effects of new doctorate degrees are the least precisely estimated of the degrees, hence conclusions are more speculative. Of the five degrees, it appears that doctorates earned have the weakest effects on employment and education attainment in the state, and the strongest effects on migration. Even so, the intrastate effects on employment and attainment are still strong. The net leakage of new doctorate degrees to other states is evidently in the range of 12 to 24 percent. 


\section{Professional and Doctorate Degrees Combined}

The intrastate labor-market effects are estimated much less precisely for professional and doctorate degrees than for the other degrees. Moreover, it could be the case the some professional degrees are misreported in the labor-market data as doctorate degrees. Thus, Table 10 reports the results when combining professional and doctorate degrees. Together, holders of these qualifications are 2.4 percent of the CPS sample. Not surprisingly, the coefficients are estimated noticeably more precisely when combining these advanced degrees, and the coefficients generally lie between their separately estimated values. Moreover, the estimated labor-market effects of new professional and doctorate degrees are generally similar to those from the lower degrees. The effect of these new advanced degrees in a state on the state's college attainment appears not quite as close to proportionate, though (the differences in the coefficients on attainment are not statistically significant, however). The proportionate point estimates on within-state college attainment range in the four specifications in Table 10 from 86 to 91 percent, and the 95 -percent confidence intervals in the four cases range from 73 percent to 101 percent.

\section{Public versus Private Degrees}

The conceptual framework discussed earlier suggests that the intrastate labor-market effects of college graduates should be about the same regardless if those graduates are from public or private institutions. Jobs for college graduates should generally be created where the graduates are located, whether from public or private institutions. There are reasons, however, why this might not be the case. Graduates from private institutions may have different preferences toward interstate migration than graduates from public institutions, possibly from 
different pre-college backgrounds and/or different college experiences. But preferences for remaining in state should not matter if the intrastate effect of college graduates on attainment is proportionate and the effect on net migration is zero. Thus, perhaps a more important reason why the public/private distinction might matter is the different public-service missions of public and private institutions of higher education. In other words, at least some of the observed positive intrastate labor-market effects of new graduates may be due to the public-service activities of institutions of higher education. Jobs for college graduates could be created through the research externalities and the public outreach efforts of the institutions, and presumably these are greater at public institutions. ${ }^{19}$ As noted earlier, the framework of this study cannot disentangle these effects. In addition, private and public institutions produce somewhat different types of college graduates; that is, graduates with a different mix of college majors. In bachelor's degrees, private institutions compared to public institutions generally have relatively fewer engineering and education majors and relatively more business majors. As will be discussed further in the next section, graduates in different fields of study could have noticeably different intrastate labor-market effects.

Hence, college graduates from public institutions could have different within-state impacts than graduates from private institutions. Moreover, the distinct effects of graduates from public institutions are obviously important for public policy toward higher education. These distinct empirical effects of graduates from public and private institutions are shown in Table 11. The coefficient estimates in Table 11 come from estimating equations (5) - (10) (plus gross migration equations) when splitting the number of college graduates in each state in each year into those from public and private institutions. All results are from OLS regressions. IV

\footnotetext{
${ }^{19}$ Indeed, in comparison to bachelor's degrees from private institutions, relatively more bachelor's degrees from
} 
regressions are not possible in this case because there are not separate instruments for the two independent variables (and because the earlier results were practically unchanged when using IV). In the interest of streamlining the presentation of these results, only the constrained cases are presented. ${ }^{20}$ The concern in this study is with the proportionate effects, and the constrained estimates are essentially the same as the unconstrained proportions. Thus, little insight would be gained from presenting both. Similarly, the results are presented for all graduates only, rather than also for only permanent-resident graduates. Professional and doctorate degrees are lumped together because, as noted earlier, their data are relatively imprecise. ${ }^{21}$

The results presented in Table 11 suggest that, for bachelor's degrees at least, graduates from public institutions do have different within-state impacts than graduates from private institutions. Compared to bachelor's degrees from private colleges, degrees from public colleges (65.8 percent of all bachelor's degrees over the time period) have significantly stronger intrastate effects on employment and attainment and a significantly weaker effect on net out-migration. Indeed, the estimated effect of public graduates on net emigration is negative and public graduates evidently have a greater than proportionate effect on intrastate college attainment. Perhaps the various public-service activities of public universities create important additional impacts in attracting and creating jobs for college graduates. The magnitude of the differences between public and private bachelor's degrees is surprising. The biggest difference between public and private graduates appears to be in their effects on gross in-migration. Evidently, degrees from private colleges in a state do little to attract college graduates from other states.

public institutions are from Carnegie Research Extensive institutions (6.8 percent compared to 18.4 percent).

${ }^{20}$ In these cases, the first five regressions are constrained by three restrictions: $\beta_{\mathrm{E}}+\beta_{\mathrm{U}}+\beta_{\mathrm{N}}+\beta_{\mathrm{M}}=1$ both for public graduates and for private graduates, and $\alpha_{E}+\alpha_{U}+\alpha_{N}+\alpha_{M}=0$.

${ }^{21}$ Moreover, many states do not have private colleges awarding professional (and doctorate) degrees, and a few do not have public colleges awarding professional degrees. 
The differences in the estimated intrastate impacts of public and private bachelor's degrees persist, though slightly smaller, when controlling for other variables that could seemingly explain them. This is shown in Appendix Table 2. Appendix Table 2 reports the same set of regressions as in the left two columns in Table 11 except that it includes additional controls for the estimated number of bachelor's degrees awarded to out-of-state (and foreign) students and for bachelor's degrees awarded in the Northeast states (CT, MA, ME, NH, NJ, NY, PA, RI, and VT) ${ }^{22,23}$ Private colleges attract disproportionate numbers of out-of-state students, and perhaps this is what drives the observed public/private differences. Private colleges are also disproportionately located in the Northeast, where perhaps historical, cultural, and/or tuition factors cause the intrastate labor-market effects of college graduates to be different than in the rest of the nation.

The coefficient estimates for out-of-state degrees and degrees in Northeast states in Appendix Table 2 are differential effects, rather than stand-alone effects like the coefficients for public and private degrees. Degrees awarded to out-of-state students and degrees from the Northeast are included in degrees from public and private institutions; thus the total effect of, say, a public degree in the Northeast is the sum of the coefficient for public degrees and the coefficient for the Northeast. ${ }^{24}$ The coefficient estimate of 0.131 for the Northeast on net outmigration, for example, indicates that graduates from Northeast have a 13.1 percent greater impact on net migration than graduates nationally.

\footnotetext{
${ }^{22}$ The results were similar when controlling for the estimated number of public degrees awarded to out-of-state (and foreign) students, the estimated number of private degrees awarded to out-of-state (and foreign) students, public degrees awarded in the Northeast states, and private degrees awarded in the Northeast states.

${ }^{23}$ An additional control for geographic size of states (along with a control for graduates from AK and HI) was also tried, but it was not statistically significant in most of the regressions and did not noticeably affect any of the coefficients on public and private degrees.
} 
Although the differences in the estimated labor-market impacts of public and private bachelor's degrees are not much affected, these additional control variables have statistically significant and economically notable labor-market effects. As expected, graduates from Northeast states have a somewhat larger effect on net emigration (although, unexpectedly, smaller effects on both gross in- and out-migration). Out-of-state (and foreign) graduates, however, have a surprising negative effect on net out-migration when also accounting for graduates from public versus private institutions. ${ }^{25}$ Perhaps out-of-state graduates, other things equal, indicates quality of higher education and hence attractiveness of graduates in determining job-creation location. ${ }^{26}$

Table 11 also shows the different effects of graduates from public versus private institutions for other degree levels. The differences for the other degrees are generally estimated with considerably less precision than for bachelor's degrees. Indeed, none of the public/private differences are statistically significant in the case of associate's degrees. Because only 20.3 percent of associate's degrees were from private institutions, the standard errors on the coefficients on private associate's degrees are relatively large. In the case of professional and doctorate degrees together, only the public/private differences gross out- and in-migration are statistically important, but there is essentially no difference in net migration. The public/private differences in migration and attainment in the case of master's degrees are statistically

\footnotetext{
${ }^{24}$ To be consistent with the constraints imposed on the coefficients on public and private degrees, the earlier conceptual framework dictates the constraints $\beta_{\mathrm{E}}+\beta_{\mathrm{U}}+\beta_{\mathrm{N}}+\beta_{\mathrm{M}}=0$ for both of these control variables (the effects sum to zero because these controls do not add to the number of graduates).

${ }^{25}$ When not separating bachelor's degrees into public and private, estimated out-of-state graduates have, as expected, a statistically significant positive effect on net out-migration. But evidently this is really a consequence of those graduates being disproportionately from in private institutions.

${ }^{26}$ To possibly add some support to this conjecture, foreign graduates, whose college-choice decisions are presumably are the most quality sensitive, apparently have a noticeably larger positive effect on within-state college attainment than out-of-state American students. The numbers of international graduates are too few, however, for this effect to be statistically significant.
} 
significant, though. Degrees from private colleges are relatively more common for master's degrees than for undergraduate degrees (of total master's degrees awarded from 1992 through $2005,45.5$ percent were from private colleges). Thus, the coefficients on private master's degrees are estimated relatively more precisely than in the undergraduate cases. As with bachelor's degrees, master's graduates from public colleges have a bigger estimated impact on college attainment in the state. Also as with bachelor's degrees, master's degrees from public colleges evidently have bigger effects on interstate migration, particularly in-migration. That is, public colleges evidently are better in attracting jobs for holders of master's degrees. ${ }^{27}$

\section{Conclusion}

An important issue in evaluating the value of state funding for higher education is the extent public investment in college students remains in the state. The popular perception about this issue focuses on the proportion of students who settle in the state after graduation - that is, on the gross rate of emigration of college students graduating in a state. This study contends that this is not the appropriate way to consider the issue. The focus should properly be on the net effect on a state's college attainment from educating college students in the state- that is, on the net rate of emigration of college students graduating in a state. The reason for emphasizing net migration is that the creation of jobs for college graduates in a state to an important extent depends endogenously on the state's supply of college graduates. The location of the creation of particular jobs largely depends on the location of workers with particular skills. Thus, the focus should be the effect of producing a highly skilled workforce through college education in creating high-skill job opportunities. A market thick with college-educated labor will attract and

\footnotetext{
${ }^{27}$ As in the case of bachelor's degrees, this is evidently not a regional effect or a geographic-size effect.
} 
create the jobs for college-educated labor. In other words, to some extent there is a Say's Law for a state's college graduation: the supply of college-educated labor largely creates its own demand.

Interstate migration occurs for a myriad of reasons. To focus on the gross emigration of a state's college graduates confuses these reasons with the specific effect of new graduates on the state's labor market. This study suggested a way of isolating the effect of new college graduates on the state's labor market.

To be specific, this study examined four exhaustive possible labor-market outcomes for new graduates in a state: employment in the state, unemployment in the state, labor-market nonparticipation in the state, and net out-migration from the state. The empirical examination of these possibilities is essentially a relatively simple accounting exercise. A simple test was also conducted on the effect of new college graduates on the labor-market earnings of college graduates in the state.

Data on college graduates in each state from 1992 through 2005 were examined with data on the employment, unemployment, nonparticipation in the labor market, and migration of college graduates in each state in the following year. Although the effects could not be estimated with great precision, the evidence clearly indicated that the effect of producing college graduates in a state on the state's college attainment was almost proportionate. That is, the intrastate effect of new college graduates on college attainment appears to be slightly less than 100 percent, but more than 90 percent. For undergraduate degrees, most of the estimation variations show that the effect is 94 percent or higher. For master's and professional degrees, the effect appears to be at least about 92 and 97 percent, respectively. The effect for doctorate degrees is more tenuously estimated, but appears to be 76 percent or higher. In other words, the intrastate labor-market 
effects were broadly the same for associate's, bachelor's, master's, and professional degrees.

The results were notably different only in the case of doctorate degrees. On average, states graduating relatively high numbers of college students evidently experience only a small net loss of graduates. In addition, the estimation variations consistently show that new college graduates in a state have essentially no impacts on unemployment and earnings of college graduates in the state. Moreover, these results appear to be causal effects rather than merely correlations. The results were robust to using a two-stage instrumental variables approach.

The separate effects of college degrees from public and private institutions were also examined. For bachelor's and master's degrees, the intrastate effects on employment and college attainment were significantly larger for degrees from public colleges than for degrees from private colleges.

There is certainly scope to improve upon the empirical work in this study. The availability of sufficient labor-market data for each state in each year for various types of college degrees currently limits the scope of feasible empirical examination. For example, the labormarket effects for individual states cannot be accurately quantified. Hopefully improvements in the data will allow this in the future. ${ }^{28}$

There are several potential avenues for additional research beyond this examination. For instance, it could be informative to examine the differences in the intrastate labor-market impacts of different college majors. The effects could differ considerably by field of study. Examination the intrastate effects of college graduates on the labor-market outcomes of non-graduates is another area that would be interesting to examine. College graduation in a state may generate

\footnotetext{
${ }^{28}$ Additional years of CPS data in the future should help. A possibly more-promising source of data in the future is the relatively new Public Use Microdata Sample of the American Community Survey. This sample is much larger than the CPS, especially for the interstate migration data. But these data only go back to 2000 (and back to 2004
} 
spillover effects into the non-college-graduate labor market. Another potentially useful area of further inquiry is exploring differences in intrastate effects from graduates of different types of postsecondary institutions (i.e., Carnegie classifications). It is unclear, however, if the limitations in the labor-market data will feasibly allow such explorations. In any event, hopefully this study has hopefully laid some useful groundwork for the further investigation of these and other issues. with the timing of the labor-market effects of college graduates is a little more problematic. 


\section{References}

Ashenfelter, O., Harmon, C., \& Oosterbeek, H. (1999). A review of estimates of the schooling/earnings relationship, with tests for publication bias. Labour Economics, 6, 453-70.

Bound, J., Groen, J., Kézdi, G., \& Turner, S. (2004). Trade in university training: Cross-state variation in the production and use of college-educated labor. Journal of Econometrics, $21,143-73$.

Bound, J. \& Holzer, H. J. (2000). Demand shifts, population adjustments, and labor market outcomes during the 1980s. Journal of Labor Economics, 18, 20-54.

Card, D. (1999). The causal effect of education on earnings. In O. Ashenfelter \& D. Card (Eds.), Handbook of labor economics (Vol. 3A). Amsterdam: Elsevier Science.

Card, D. \& Lemieux, T. (2001). Can falling supply explain the rising return to college for younger men? A cohort-based analysis. Quarterly Journal of Economics, 116, 705-46.

Cunningham, A. F., Wellman, J. V., Clinedinst, M. E., \& Merisotis, J. P. (2001). Study of college costs and prices, 1988-89 to 1997-98. Washington, DC: National Center for Education Statistics.

Freeman, R. (1976). The overeducated American. New York: Academic Press.

Fortin, N. M. (2006). Higher-education policies and the college wage premium: Cross-state evidence from the 1990s. American Economic Review, 96, 959-87.

Gottlieb, P. D. \& Joseph, G. (2006). College-to-work migration of technology graduates and holders of doctorates within the United States. Journal of Regional Science, 46, 627-59.

Groen, J. A. (2004). The effect of college location on migration of college-educated labor. Journal of Econometrics, 21, 125-42

Hovey, H. A. (1999). State spending for higher education in the next decade: The battle to sustain current support. Washington, DC: National Center for Public Policy and Higher Education.

Justman, M. \& Thisse, J.-F. (1997). Implications of the mobility of skilled labor for local public funding of higher education. Economics Letters, 55, 409-12.

Katz, L. F. \& Autor, D. H. (1999). Changes in the wage structure and earnings inequality. In O. Ashenfelter \& D. Card (Eds.), Handbook of labor economics (Vol. 3A). Amsterdam: Elsevier Science. 
Kodrzycki, Y. K. (2001). Migration of recent college graduates: Evidence from the national survey of youth. New England Economic Review, 7, 13-34.

Levy, F. \& Murname, R. J. (1992). U.S. earnings levels and earnings inequality: A review of recent trends and proposed explanations. Journal of Economic Literature, 30, 1333-81.

Long, L. E. (1988). Migration and residential mobility in the United States. New York: Russell Sage.

Moretti, E. (2004). Estimating the social return to higher education: Evidence from longitudinal and repeated cross-sectional data. Journal of Econometrics, 21, 175-212.

National Center for Public Policy and Higher Education. (2003). College affordability in jeopardy. San Jose, CA: Author.

Parsad, B. \& Gray, L. (2005). Interstate migration patterns of recent bachelor's and master's degrees in science and engineering. Arlington, VA: National Science Foundation.

Sanderson, A \& Dugoni, B. (2002). Interstate migration patterns of recent science and engineering doctorate recipients. Arlington, VA: National Science Foundation.

Schachter, J. (2001). Geographic mobility: March 1999 to March 2000. Current population reports: Population characteristics. Washington, DC: U.S. Census Bureau.

Strathman, J. G. (1994). Migration, benefit spillovers and state support of higher education. Urban Studies, 31, 913-20.

Tornatzky, L. G., Gray, D., Tarant, S. A., \& Howe, J. E. (1998). Where have all the students gone? Interstate migration of recent science and engineering graduates. Research Triangle Park, NC: Southern Growth Policies Board.

Tornatzky, L. G., Gray, D. O., Tarant, S. A., \& Zimmer, C. (2001). Who will stay and who will leave? Research Triangle Park, NC: Southern Growth Policies Board.

Wildasin, D. E. (2000). Labor-market integration, investment in risky human capital, and fiscal competition. American Economic Review, 90, 73-95. 


\section{Table 1}

\section{CPS Micro-Data Summary} 1992-2005

\begin{tabular}{|c|c|c|c|c|c|c|}
\hline & $\begin{array}{r}\text { No } \\
\text { Degree }\end{array}$ & $\begin{array}{r}\text { Associate's } \\
\text { Degree } \\
\end{array}$ & $\begin{array}{r}\text { Bachelor's } \\
\text { Degree } \\
\end{array}$ & $\begin{array}{r}\text { Master's } \\
\text { Degree } \\
\end{array}$ & $\begin{array}{r}\text { Professional } \\
\text { Degree } \\
\end{array}$ & $\begin{array}{r}\text { Doctorate } \\
\text { Degree }\end{array}$ \\
\hline Employment Proportion & 0.671 & 0.802 & 0.814 & 0.829 & 0.877 & 0.870 \\
\hline Unemployment Proportion & 0.039 & 0.027 & 0.022 & 0.019 & 0.011 & 0.014 \\
\hline Nonparticipation Proportion & 0.290 & 0.171 & 0.163 & 0.153 & 0.112 & 0.117 \\
\hline Migration Proportion & 0.028 & 0.027 & 0.040 & 0.036 & 0.039 & 0.048 \\
\hline Mean Real Weekly Wages & $\$ 613.70$ & $\$ 748.10$ & $\$ 1,016.61$ & $\$ 1,224.67$ & $\$ 1,572.05$ & $\$ 1,536.83$ \\
\hline Percent of Sample & $66.4 \%$ & $8.4 \%$ & $17.1 \%$ & $5.7 \%$ & $1.4 \%$ & $1.1 \%$ \\
\hline
\end{tabular}




\section{Table 2}

\section{State-Year Data Means}

1992-2005

\begin{tabular}{|c|c|c|c|c|c|}
\hline & $\begin{array}{r}\text { Associate's } \\
\text { Degree } \\
\end{array}$ & $\begin{array}{r}\text { Bachelor's } \\
\text { Degree } \\
\end{array}$ & $\begin{array}{r}\text { Master's } \\
\text { Degree }\end{array}$ & $\begin{array}{r}\text { Professional } \\
\text { Degree } \\
\end{array}$ & $\begin{array}{r}\text { Doctorate } \\
\text { Degree } \\
\end{array}$ \\
\hline New Degrees in IPEDS & 11,583 & 24,577 & 8,807 & 1,537 & 901 \\
\hline$\Delta$ Employment & 8,223 & 16,420 & 4,624 & 876 & 1,229 \\
\hline$\Delta$ Unemployment & 83 & 62 & 16 & -7 & 23 \\
\hline$\Delta$ Nonparticipation & 2,328 & 3,399 & 1,626 & 284 & 229 \\
\hline Net Out-Migration & -38 & -202 & -99 & -69 & -28 \\
\hline$\triangle$ Degrees in CPS & 10,671 & 16,621 & 6,365 & 1,222 & 1,453 \\
\hline Gross Out-Migration & 6,951 & 21,087 & 5,946 & 1,518 & 1,362 \\
\hline$\Delta \ln ($ Wages $) \times 100$ & -0.442 & -0.107 & -0.211 & -0.092 & -0.196 \\
\hline Flow Rate of New Degrees & 0.042 & 0.047 & 0.046 & 0.034 & 0.025 \\
\hline
\end{tabular}




\section{Table 3}

\section{Estimated Intrastate Labor-Market Impacts of New Bachelor's Degrees}

\section{Coefficients Unconstrained}

\begin{tabular}{|c|c|c|c|c|}
\hline & \multicolumn{2}{|c|}{ OLS } & \multicolumn{2}{|c|}{ IV } \\
\hline & $\begin{array}{r}\text { All } \\
\text { Graduates } \\
\end{array}$ & $\begin{array}{r}\text { Resident } \\
\text { Graduates }\end{array}$ & $\begin{array}{r}\text { All } \\
\text { Graduates } \\
\end{array}$ & $\begin{array}{r}\text { Resident } \\
\text { Graduates }\end{array}$ \\
\hline$\Delta$ Employment & $\begin{array}{l}0.537 \\
(0.043)\end{array}$ & $\begin{array}{c}0.580 \\
(0.051)\end{array}$ & $\begin{array}{l}0.562 \\
(0.045)\end{array}$ & $\begin{array}{c}0.609 \\
(0.053)\end{array}$ \\
\hline$\Delta$ Unemployment & $\begin{array}{r}-0.006 \\
(0.010)\end{array}$ & $\begin{array}{l}-0.001 \\
(0.012)\end{array}$ & $\begin{array}{r}-0.007 \\
(0.010)\end{array}$ & $\begin{array}{r}-0.003 \\
(0.013)\end{array}$ \\
\hline$\Delta$ Nonparticipation & $\begin{array}{l}0.136 \\
(0.023)\end{array}$ & $\begin{array}{l}0.158 \\
(0.029)\end{array}$ & $\begin{array}{l}0.143 \\
(0.024)\end{array}$ & $\begin{array}{l}0.168 \\
(0.030)\end{array}$ \\
\hline Net Out-Migration & $\begin{array}{l}0.041 \\
(0.020)\end{array}$ & $\begin{array}{l}0.001 \\
(0.023)\end{array}$ & $\begin{array}{l}0.022 \\
(0.020)\end{array}$ & $\begin{array}{l}-0.020 \\
(0.024)\end{array}$ \\
\hline$\Delta$ Attainment & $\begin{array}{l}0.667 \\
(0.052)\end{array}$ & $\begin{array}{l}0.736 \\
(0.063)\end{array}$ & $\begin{array}{l}0.697 \\
(0.053)\end{array}$ & $\begin{array}{l}0.775 \\
(0.064)\end{array}$ \\
\hline$\Delta \ln$ (Wages) & $\begin{array}{r}-0.004 \\
(0.109)\end{array}$ & $\begin{array}{r}-0.003 \\
(0.133)\end{array}$ & $\begin{array}{l}-0.128 \\
(0.220)\end{array}$ & $\begin{array}{r}-0.025 \\
(0.270)\end{array}$ \\
\hline Out-Migration & $\begin{array}{l}0.658 \\
(0.016)\end{array}$ & $\begin{array}{l}0.673 \\
(0.018)\end{array}$ & $\begin{array}{l}0.673 \\
(0.016)\end{array}$ & $\begin{array}{l}0.689 \\
(0.019)\end{array}$ \\
\hline In-Migration & $\begin{array}{l}0.617 \\
(0.021)\end{array}$ & $\begin{array}{l}0.672 \\
(0.025)\end{array}$ & $\begin{array}{l}0.651 \\
(0.021)\end{array}$ & $\begin{array}{l}0.709 \\
(0.025)\end{array}$ \\
\hline$\beta_{\mathrm{A}} /\left(\beta_{\mathrm{A}}+\beta_{\mathrm{M}}\right)$ & $\begin{array}{l}0.942 \\
(0.027)\end{array}$ & $\begin{array}{l}0.999 \\
(0.031)\end{array}$ & $\begin{array}{l}0.969 \\
(0.028)\end{array}$ & $\begin{array}{l}1.027 \\
(0.032)\end{array}$ \\
\hline Observations & 700 & 550 & 700 & 550 \\
\hline
\end{tabular}

Standard errors are in parentheses. 


\section{Table 4}

Estimated Intrastate Labor-Market Impacts of New Bachelor's Degrees

\section{Coefficients Constrained}

\begin{tabular}{|c|c|c|c|c|}
\hline & \multicolumn{2}{|c|}{ OLS } & \multicolumn{2}{|c|}{ IV } \\
\hline & $\begin{array}{r}\text { All } \\
\text { Graduates } \\
\end{array}$ & $\begin{array}{r}\text { Resident } \\
\text { Graduates }\end{array}$ & $\begin{array}{r}\text { All } \\
\text { Graduates } \\
\end{array}$ & $\begin{array}{r}\text { Resident } \\
\text { Graduates }\end{array}$ \\
\hline$\Delta$ Employment & $\begin{array}{l}0.724 \\
(0.026)\end{array}$ & $\begin{array}{l}0.747 \\
(0.030)\end{array}$ & $\begin{array}{l}0.741 \\
(0.026)\end{array}$ & $\begin{array}{c}0.764 \\
(0.030)\end{array}$ \\
\hline$\Delta$ Unemployment & $\begin{array}{r}-0.000 \\
(0.011)\end{array}$ & $\begin{array}{l}0.002 \\
(0.013)\end{array}$ & $\begin{array}{r}-0.002 \\
(0.011)\end{array}$ & $\begin{array}{l}0.001 \\
(0.013)\end{array}$ \\
\hline$\Delta$ Nonparticipation & $\begin{array}{l}0.205 \\
(0.020)\end{array}$ & $\begin{array}{l}0.225 \\
(0.024)\end{array}$ & $\begin{array}{l}0.209 \\
(0.020)\end{array}$ & $\begin{array}{l}0.230 \\
(0.024)\end{array}$ \\
\hline Net Out-Migration & $\begin{array}{l}0.071 \\
(0.019)\end{array}$ & $\begin{array}{l}0.026 \\
(0.022)\end{array}$ & $\begin{array}{l}0.053 \\
(0.020)\end{array}$ & $\begin{array}{l}0.004 \\
(0.023)\end{array}$ \\
\hline$\Delta$ Attainment & $\begin{array}{l}0.929 \\
(0.019)\end{array}$ & $\begin{array}{r}0.974 \\
(0.022)\end{array}$ & $\begin{array}{l}0.947 \\
(0.020)\end{array}$ & $\begin{array}{l}0.996 \\
(0.023)\end{array}$ \\
\hline Observations & 700 & 550 & 700 & 550 \\
\hline
\end{tabular}

Standard errors are in parentheses. 


\section{Table 5}

\section{Estimated Intrastate Labor-Market Impacts of New Associate's Degrees}

\begin{tabular}{|c|c|c|c|c|}
\hline & \multicolumn{2}{|c|}{ OLS } & \multicolumn{2}{|c|}{ IV } \\
\hline & $\begin{array}{r}\text { All } \\
\text { Graduates } \\
\end{array}$ & $\begin{array}{r}\text { Resident } \\
\text { Graduates }\end{array}$ & $\begin{array}{r}\text { All } \\
\text { Graduates } \\
\end{array}$ & $\begin{array}{r}\text { Resident } \\
\text { Graduates }\end{array}$ \\
\hline$\Delta$ Employment & $\begin{array}{l}0.413 \\
(0.054)\end{array}$ & $\begin{array}{l}0.361 \\
(0.059)\end{array}$ & $\begin{array}{l}0.464 \\
(0.058)\end{array}$ & $\begin{array}{c}0.385 \\
(0.064)\end{array}$ \\
\hline$\Delta$ Unemployment & $\begin{array}{r}-0.004 \\
(0.013)\end{array}$ & $\begin{array}{r}-0.007 \\
(0.014)\end{array}$ & $\begin{array}{c}0.002 \\
(0.014)\end{array}$ & $\begin{array}{l}0.000 \\
(0.015)\end{array}$ \\
\hline$\Delta$ Nonparticipation & $\begin{array}{l}0.178 \\
(0.021)\end{array}$ & $\begin{array}{l}0.168 \\
(0.024)\end{array}$ & $\begin{array}{l}0.201 \\
(0.022)\end{array}$ & $\begin{array}{l}0.187 \\
(0.026)\end{array}$ \\
\hline Net Out-Migration & $\begin{array}{r}0.004 \\
(0.017)\end{array}$ & $\begin{array}{r}-0.006 \\
(0.019)\end{array}$ & $\begin{array}{l}0.039 \\
(0.018)\end{array}$ & $\begin{array}{c}0.017 \\
(0.021)\end{array}$ \\
\hline$\Delta$ Attainment & $\begin{array}{r}0.587 \\
(0.062)\end{array}$ & $\begin{array}{l}0.521 \\
(0.066)\end{array}$ & $\begin{array}{l}0.666 \\
(0.066)\end{array}$ & $\begin{array}{l}0.572 \\
(0.071)\end{array}$ \\
\hline$\Delta \ln$ (Wages) & $\begin{array}{r}0.184 \\
(0.170)\end{array}$ & $\begin{array}{l}0.059 \\
(0.210)\end{array}$ & $\begin{array}{l}0.689 \\
(0.732)\end{array}$ & $\begin{array}{l}0.108 \\
(0.882)\end{array}$ \\
\hline Out-Migration & $\begin{array}{r}0.364 \\
(0.012)\end{array}$ & $\begin{array}{l}0.374 \\
(0.014)\end{array}$ & $\begin{array}{l}0.387 \\
(0.014)\end{array}$ & $\begin{array}{l}0.386 \\
(0.016)\end{array}$ \\
\hline In-Migration & $\begin{array}{l}0.360 \\
(0.015)\end{array}$ & $\begin{array}{l}0.380 \\
(0.016)\end{array}$ & $\begin{array}{l}0.348 \\
(0.017)\end{array}$ & $\begin{array}{l}0.369 \\
(0.019)\end{array}$ \\
\hline$\beta_{\mathrm{A}} /\left(\beta_{\mathrm{A}}+\beta_{\mathrm{M}}\right)$ & $\begin{array}{l}0.993 \\
(0.029)\end{array}$ & $\begin{array}{l}1.012 \\
(0.038)\end{array}$ & $\begin{array}{l}0.944 \\
(0.025)\end{array}$ & $\begin{array}{l}0.971 \\
(0.035)\end{array}$ \\
\hline Observations & 700 & 550 & 700 & 550 \\
\hline
\end{tabular}

Standard errors are in parentheses. 


\section{Table 6}

Estimated Intrastate Labor-Market Impacts of New Associate's Degrees

\section{Coefficients Constrained}

\begin{tabular}{|c|c|c|c|c|}
\hline & \multicolumn{2}{|c|}{ OLS } & \multicolumn{2}{|c|}{ IV } \\
\hline & $\begin{array}{r}\text { All } \\
\text { Graduates }\end{array}$ & $\begin{array}{r}\text { Resident } \\
\text { Graduates }\end{array}$ & $\begin{array}{r}\text { All } \\
\text { Graduates }\end{array}$ & $\begin{array}{r}\text { Resident } \\
\text { Graduates }\end{array}$ \\
\hline$\Delta$ Employment & $\begin{array}{l}0.710 \\
(0.027)\end{array}$ & $\begin{array}{l}0.710 \\
(0.030)\end{array}$ & $\begin{array}{l}0.685 \\
(0.028)\end{array}$ & $\begin{array}{l}0.689 \\
(0.032)\end{array}$ \\
\hline$\Delta$ Unemployment & $\begin{array}{l}0.022 \\
(0.013)\end{array}$ & $\begin{array}{l}0.020 \\
(0.015)\end{array}$ & $\begin{array}{l}0.019 \\
(0.014)\end{array}$ & $\begin{array}{l}0.021 \\
(0.015)\end{array}$ \\
\hline$\Delta$ Nonparticipation & $\begin{array}{l}0.233 \\
(0.019)\end{array}$ & $\begin{array}{l}0.239 \\
(0.022)\end{array}$ & $\begin{array}{l}0.239 \\
(0.020)\end{array}$ & $\begin{array}{l}0.245 \\
(0.024)\end{array}$ \\
\hline Net Out-Migration & $\begin{array}{l}0.034 \\
(0.017)\end{array}$ & $\begin{array}{l}0.031 \\
(0.020)\end{array}$ & $\begin{array}{l}0.057 \\
(0.018)\end{array}$ & $\begin{array}{l}0.044 \\
(0.021)\end{array}$ \\
\hline$\Delta$ Attainment & $\begin{array}{l}0.966 \\
(0.017)\end{array}$ & $\begin{array}{r}0.969 \\
(0.020)\end{array}$ & $\begin{array}{l}0.943 \\
(0.018)\end{array}$ & $\begin{array}{l}0.956 \\
(0.021)\end{array}$ \\
\hline Observations & 700 & 550 & 700 & 550 \\
\hline
\end{tabular}

Standard errors are in parentheses. 


\section{Table 7}

\section{Estimated Intrastate Labor-Market Impacts of New Master's Degrees}

OLS

\begin{tabular}{|c|c|c|c|c|}
\hline & \multicolumn{2}{|c|}{$\underline{\text { Coefficients Unconstrained }}$} & \multicolumn{2}{|c|}{ Coefficients Constrained } \\
\hline & $\begin{array}{r}\text { All } \\
\text { Graduates }\end{array}$ & $\begin{array}{c}\text { Resident } \\
\text { Graduates }\end{array}$ & $\begin{array}{r}\text { All } \\
\text { Graduates }\end{array}$ & $\begin{array}{r}\text { Resident } \\
\text { Graduates }\end{array}$ \\
\hline$\Delta$ Employment & $\begin{array}{l}0.444 \\
(0.056)\end{array}$ & $\begin{array}{c}0.563 \\
(0.072)\end{array}$ & $\begin{array}{l}0.682 \\
(0.029)\end{array}$ & $\begin{array}{r}0.677 \\
(0.037)\end{array}$ \\
\hline$\Delta$ Unemployment & $\begin{array}{r}-0.009 \\
(0.011)\end{array}$ & $\begin{array}{l}-0.003 \\
(0.014)\end{array}$ & $\begin{array}{l}0.007 \\
(0.011)\end{array}$ & $\begin{array}{r}0.001 \\
(0.014)\end{array}$ \\
\hline$\Delta$ Nonparticipation & $\begin{array}{l}0.189 \\
(0.022)\end{array}$ & $\begin{array}{l}0.224 \\
(0.029)\end{array}$ & $\begin{array}{l}0.232 \\
(0.021)\end{array}$ & $\begin{array}{r}0.244 \\
(0.027)\end{array}$ \\
\hline Net Out-Migration & $\begin{array}{l}0.045 \\
(0.022)\end{array}$ & $\begin{array}{l}0.063 \\
(0.029)\end{array}$ & $\begin{array}{l}0.079 \\
(0.021)\end{array}$ & $\begin{array}{r}0.078 \\
(0.028)\end{array}$ \\
\hline$\Delta$ Attainment & $\begin{array}{l}0.624 \\
(0.062)\end{array}$ & $\begin{array}{r}0.784 \\
(0.080)\end{array}$ & $\begin{array}{l}0.921 \\
(0.021)\end{array}$ & $\begin{array}{r}0.922 \\
(0.028)\end{array}$ \\
\hline$\Delta \ln ($ Wages $)$ & $\begin{array}{l}0.040 \\
(0.202)\end{array}$ & $\begin{array}{r}-0.038 \\
(0.248)\end{array}$ & & \\
\hline Out-Migration & $\begin{array}{l}0.455 \\
(0.017)\end{array}$ & $\begin{array}{l}0.564 \\
(0.022)\end{array}$ & & \\
\hline In-Migration & $\begin{array}{r}0.410 \\
(0.019)\end{array}$ & $\begin{array}{r}0.502 \\
(0.025)\end{array}$ & & \\
\hline$\beta_{\mathrm{A}} /\left(\beta_{\mathrm{A}}+\beta_{\mathrm{M}}\right)$ & $\begin{array}{l}0.932 \\
(0.031)\end{array}$ & $\begin{array}{l}0.926 \\
(0.033)\end{array}$ & & \\
\hline Observations & 700 & 550 & 700 & 550 \\
\hline
\end{tabular}

Standard errors are in parentheses. 


\section{Table 8}

\section{Estimated Intrastate Labor-Market Impacts of New Professional Degrees}

OLS

\begin{tabular}{|c|c|c|c|c|}
\hline & \multicolumn{2}{|c|}{$\underline{\text { Coefficients Unconstrained }}$} & \multicolumn{2}{|c|}{ Coefficients Constrained } \\
\hline & $\begin{array}{r}\text { All } \\
\text { Graduates }\end{array}$ & $\begin{array}{c}\text { Resident } \\
\text { Graduates }\end{array}$ & $\begin{array}{r}\text { All } \\
\text { Graduates }\end{array}$ & $\begin{array}{r}\text { Resident } \\
\text { Graduates }\end{array}$ \\
\hline$\Delta$ Employment & $\begin{array}{l}0.629 \\
(0.156)\end{array}$ & $\begin{array}{l}0.469 \\
(0.182)\end{array}$ & $\begin{array}{l}0.773 \\
(0.071)\end{array}$ & $\begin{array}{l}0.759 \\
(0.084)\end{array}$ \\
\hline$\Delta$ Unemployment & $\begin{array}{l}0.006 \\
(0.022)\end{array}$ & $\begin{array}{r}0.006 \\
(0.026)\end{array}$ & $\begin{array}{l}0.008 \\
(0.022)\end{array}$ & $\begin{array}{l}0.011 \\
(0.026)\end{array}$ \\
\hline$\Delta$ Nonparticipation & $\begin{array}{l}0.171 \\
(0.054)\end{array}$ & $\begin{array}{r}0.162 \\
(0.066)\end{array}$ & $\begin{array}{l}0.186 \\
(0.052)\end{array}$ & $\begin{array}{r}0.197 \\
(0.064)\end{array}$ \\
\hline Net Out-Migration & $\begin{array}{l}0.021 \\
(0.057)\end{array}$ & $\begin{array}{r}0.006 \\
(0.065)\end{array}$ & $\begin{array}{l}0.032 \\
(0.056)\end{array}$ & $\begin{array}{r}0.033 \\
(0.064)\end{array}$ \\
\hline$\Delta$ Attainment & $\begin{array}{l}0.806 \\
(0.165)\end{array}$ & $\begin{array}{l}0.637 \\
(0.194)\end{array}$ & $\begin{array}{l}0.968 \\
(0.056)\end{array}$ & $\begin{array}{l}0.967 \\
(0.064)\end{array}$ \\
\hline$\Delta \ln$ (Wages) & $\begin{array}{r}-0.062 \\
(0.333)\end{array}$ & $\begin{array}{l}0.392 \\
(0.410)\end{array}$ & & \\
\hline Out-Migration & $\begin{array}{l}0.712 \\
(0.039)\end{array}$ & $\begin{array}{l}0.759 \\
(0.046)\end{array}$ & & \\
\hline In-Migration & $\begin{array}{r}0.692 \\
(0.046)\end{array}$ & $\begin{array}{c}0.753 \\
(0.054)\end{array}$ & & \\
\hline$\beta_{\mathrm{A}} /\left(\beta_{\mathrm{A}}+\beta_{\mathrm{M}}\right)$ & $\begin{array}{l}0.975 \\
(0.068)\end{array}$ & $\begin{array}{l}0.990 \\
(0.101)\end{array}$ & & \\
\hline Observations & 700 & 550 & 700 & 550 \\
\hline
\end{tabular}

Standard errors are in parentheses. 


\section{Table 9}

\section{Estimated Intrastate Labor-Market Impacts of New Doctorate Degrees}

OLS

\begin{tabular}{|c|c|c|c|c|}
\hline & \multicolumn{2}{|c|}{$\underline{\text { Coefficients Unconstrained }}$} & \multicolumn{2}{|c|}{ Coefficients Constrained } \\
\hline & $\begin{array}{r}\text { All } \\
\text { Graduates }\end{array}$ & $\begin{array}{c}\text { Resident } \\
\text { Graduates }\end{array}$ & $\begin{array}{r}\text { All } \\
\text { Graduates }\end{array}$ & $\begin{array}{r}\text { Resident } \\
\text { Graduates }\end{array}$ \\
\hline$\Delta$ Employment & $\begin{array}{l}1.095 \\
(0.234)\end{array}$ & $\begin{array}{l}1.325 \\
(0.353)\end{array}$ & $\begin{array}{l}0.659 \\
(0.116)\end{array}$ & $\begin{array}{l}0.492 \\
(0.182)\end{array}$ \\
\hline$\Delta$ Unemployment & $\begin{array}{l}0.012 \\
(0.030)\end{array}$ & $\begin{array}{l}-0.013 \\
(0.046)\end{array}$ & $\begin{array}{l}0.010 \\
(0.031)\end{array}$ & $\begin{array}{r}-0.022 \\
(0.048)\end{array}$ \\
\hline$\Delta$ Nonparticipation & $\begin{array}{r}0.258 \\
(0.085)\end{array}$ & $\begin{array}{c}0.401 \\
(0.129)\end{array}$ & $\begin{array}{r}0.198 \\
(0.080)\end{array}$ & $\begin{array}{l}0.292 \\
(0.124)\end{array}$ \\
\hline Net Out-Migration & $\begin{array}{r}0.194 \\
(0.095)\end{array}$ & $\begin{array}{c}0.379 \\
(0.147)\end{array}$ & $\begin{array}{l}0.134 \\
(0.091)\end{array}$ & $\begin{array}{l}0.237 \\
(0.138)\end{array}$ \\
\hline$\Delta$ Attainment & $\begin{array}{l}1.365 \\
(0.249)\end{array}$ & $\begin{array}{c}1.713 \\
(0.370)\end{array}$ & $\begin{array}{l}0.866 \\
(0.091)\end{array}$ & $\begin{array}{l}0.763 \\
(0.138)\end{array}$ \\
\hline$\Delta \ln$ (Wages) & $\begin{array}{l}1.188 \\
(0.467)\end{array}$ & $\begin{array}{l}0.309 \\
(0.753)\end{array}$ & & \\
\hline Out-Migration & $\begin{array}{l}1.115 \\
(0.065)\end{array}$ & $\begin{array}{r}1.597 \\
(0.099)\end{array}$ & & \\
\hline In-Migration & $\begin{array}{r}0.922 \\
(0.074)\end{array}$ & $\begin{array}{r}1.218 \\
(0.113)\end{array}$ & & \\
\hline$\beta_{\mathrm{A}} /\left(\beta_{\mathrm{A}}+\beta_{\mathrm{M}}\right)$ & $\begin{array}{l}0.876 \\
(0.058)\end{array}$ & $\begin{array}{l}0.819 \\
(0.067)\end{array}$ & & \\
\hline Observations & 700 & 550 & 700 & 550 \\
\hline
\end{tabular}

Standard errors are in parentheses. 


\section{Table 10}

\section{Estimated Intrastate Impacts of New Professional and Doctorate Degrees Together} OLS

\begin{tabular}{|c|c|c|c|c|}
\hline & \multicolumn{2}{|c|}{$\underline{\text { Coefficients Unconstrained }}$} & \multicolumn{2}{|c|}{ Coefficients Constrained } \\
\hline & $\begin{array}{r}\text { All } \\
\text { Graduates } \\
\end{array}$ & $\begin{array}{r}\text { Resident } \\
\text { Graduates }\end{array}$ & $\begin{array}{r}\text { All } \\
\text { Graduates } \\
\end{array}$ & $\begin{array}{r}\text { Resident } \\
\text { Graduates }\end{array}$ \\
\hline$\Delta$ Employment & $\begin{array}{r}0.778 \\
(0.133)\end{array}$ & $\begin{array}{r}0.698 \\
(0.167)\end{array}$ & $\begin{array}{r}0.707 \\
(0.067)\end{array}$ & $\begin{array}{l}0.638 \\
(0.086)\end{array}$ \\
\hline$\Delta$ Unemployment & $\begin{array}{r}0.010 \\
(0.017)\end{array}$ & $\begin{array}{r}0.002 \\
(0.023)\end{array}$ & $\begin{array}{r}0.010 \\
(0.017)\end{array}$ & $\begin{array}{r}0.002 \\
(0.023)\end{array}$ \\
\hline$\Delta$ Nonparticipation & $\begin{array}{l}0.198 \\
(0.048)\end{array}$ & $\begin{array}{r}0.234 \\
(0.065)\end{array}$ & $\begin{array}{l}0.188 \\
(0.045)\end{array}$ & $\begin{array}{l}0.224 \\
(0.061)\end{array}$ \\
\hline Net Out-Migration & $\begin{array}{l}0.101 \\
(0.054)\end{array}$ & $\begin{array}{c}0.143 \\
(0.069)\end{array}$ & $\begin{array}{l}0.096 \\
(0.054)\end{array}$ & $\begin{array}{r}0.136 \\
(0.067)\end{array}$ \\
\hline$\Delta$ Attainment & $\begin{array}{r}0.986 \\
(0.144)\end{array}$ & $\begin{array}{c}0.935 \\
(0.181)\end{array}$ & $\begin{array}{l}0.904 \\
(0.053)\end{array}$ & $\begin{array}{l}0.864 \\
(0.067)\end{array}$ \\
\hline$\Delta \ln ($ Wages $)$ & $\begin{array}{l}-0.187 \\
(0.327)\end{array}$ & $\begin{array}{l}0.009 \\
(0.434)\end{array}$ & & \\
\hline Out-Migration & $\begin{array}{r}0.873 \\
(0.037)\end{array}$ & $\begin{array}{r}1.040 \\
(0.048)\end{array}$ & & \\
\hline In-Migration & $\begin{array}{l}0.772 \\
(0.045)\end{array}$ & $\begin{array}{r}0.897 \\
(0.058)\end{array}$ & & \\
\hline$\beta_{\mathrm{A}} /\left(\beta_{\mathrm{A}}+\beta_{\mathrm{M}}\right)$ & $\begin{array}{l}0.907 \\
(0.049)\end{array}$ & $\begin{array}{l}0.867 \\
(0.063)\end{array}$ & & \\
\hline Observations & 700 & 550 & 700 & 550 \\
\hline
\end{tabular}

Standard errors are in parentheses. 


\section{Table 11}

Estimated Intrastate Labor-Market Impacts of All New Public and Private Degrees

\section{OLS, Coefficients Constrained}

\begin{tabular}{|c|c|c|c|c|c|c|c|c|}
\hline & \multicolumn{2}{|c|}{ Bachelor's } & \multicolumn{2}{|c|}{ Associate's } & \multicolumn{2}{|c|}{ Master's } & \multicolumn{2}{|c|}{$\begin{array}{l}\text { Professional } \\
\text { \& Doctorate }\end{array}$} \\
\hline & Public & Private & Public & Private & Public & Private & Public & Private \\
\hline$\Delta$ Employment & $\begin{array}{r}0.966 \\
(0.055)\end{array}$ & $\begin{array}{r}0.334 \\
(0.082)\end{array}$ & $\begin{array}{r}0.663 \\
(0.053)\end{array}$ & $\begin{array}{r}0.904 \\
(0.188)\end{array}$ & $\begin{array}{r}0.801 \\
(0.087)\end{array}$ & $\begin{array}{r}0.607 \\
(0.059)\end{array}$ & $\begin{array}{r}0.664 \\
(0.218)\end{array}$ & $\begin{array}{r}0.728 \\
(0.121)\end{array}$ \\
\hline$\Delta$ Unemployment & $\begin{array}{l}-0.007 \\
(0.024)\end{array}$ & $\begin{array}{l}0.011 \\
(0.035)\end{array}$ & $\begin{array}{r}0.030 \\
(0.025)\end{array}$ & $\begin{array}{l}-0.008 \\
(0.091)\end{array}$ & $\begin{array}{l}0.025 \\
(0.032)\end{array}$ & $\begin{array}{l}-0.004 \\
(0.022)\end{array}$ & $\begin{array}{l}-0.003 \\
(0.057)\end{array}$ & $\begin{array}{r}0.016 \\
(0.032)\end{array}$ \\
\hline$\Delta$ Nonparticipation & $\begin{array}{r}0.212 \\
(0.044)\end{array}$ & $\begin{array}{r}0.194 \\
(0.065)\end{array}$ & $\begin{array}{r}0.283 \\
(0.038)\end{array}$ & $\begin{array}{r}0.029 \\
(0.134)\end{array}$ & $\begin{array}{r}0.316 \\
(0.062)\end{array}$ & $\begin{array}{r}0.178 \\
(0.043)\end{array}$ & $\begin{array}{r}0.238 \\
(0.146)\end{array}$ & $\begin{array}{r}0.163 \\
(0.081)\end{array}$ \\
\hline Net Out-Migration & $\begin{array}{l}-0.171 \\
(0.041)\end{array}$ & $\begin{array}{r}0.462 \\
(0.061)\end{array}$ & $\begin{array}{r}0.024 \\
(0.033)\end{array}$ & $\begin{array}{r}0.076 \\
(0.119)\end{array}$ & $\begin{array}{l}-0.141 \\
(0.061)\end{array}$ & $\begin{array}{r}0.219 \\
(0.042)\end{array}$ & $\begin{array}{r}0.100 \\
(0.176)\end{array}$ & $\begin{array}{r}0.093 \\
(0.098)\end{array}$ \\
\hline$\Delta$ Attainment & $\begin{array}{r}1.171 \\
(0.041)\end{array}$ & $\begin{array}{r}0.538 \\
(0.061)\end{array}$ & $\begin{array}{r}0.976 \\
(0.033)\end{array}$ & $\begin{array}{r}0.924 \\
(0.119)\end{array}$ & $\begin{array}{r}1.141 \\
(0.061)\end{array}$ & $\begin{array}{r}0.781 \\
(0.042)\end{array}$ & $\begin{array}{r}0.900 \\
(0.176)\end{array}$ & $\begin{array}{r}0.907 \\
(0.098)\end{array}$ \\
\hline$\Delta \ln ($ Wages $)$ & $\begin{array}{l}-0.001 \\
(0.140)\end{array}$ & $\begin{array}{l}-0.007 \\
(0.156)\end{array}$ & $\begin{array}{r}0.198 \\
(0.201)\end{array}$ & $\begin{array}{l}0.161 \\
(0.240)\end{array}$ & $\begin{array}{l}0.061 \\
(0.242)\end{array}$ & $\begin{array}{r}0.025 \\
(0.224)\end{array}$ & $\begin{array}{l}-0.141 \\
(0.423)\end{array}$ & $\begin{array}{l}-0.230 \\
(0.413)\end{array}$ \\
\hline Out-Migration & $\begin{array}{r}0.756 \\
(0.034)\end{array}$ & $\begin{array}{r}0.504 \\
(0.050)\end{array}$ & $\begin{array}{r}0.383 \\
(0.025)\end{array}$ & $\begin{array}{r}0.287 \\
(0.088)\end{array}$ & $\begin{array}{r}0.604 \\
(0.050)\end{array}$ & $\begin{array}{r}0.361 \\
(0.034)\end{array}$ & $\begin{array}{r}1.352 \\
(0.121)\end{array}$ & $\begin{array}{r}0.640 \\
(0.067)\end{array}$ \\
\hline In-Migration & $\begin{array}{r}0.938 \\
(0.045)\end{array}$ & $\begin{array}{r}0.107 \\
(0.066)\end{array}$ & $\begin{array}{r}0.381 \\
(0.029)\end{array}$ & $\begin{array}{r}0.276 \\
(0.103)\end{array}$ & $\begin{array}{c}0.764 \\
(0.054)\end{array}$ & $\begin{array}{r}0.185 \\
(0.037)\end{array}$ & $\begin{array}{r}1.260 \\
(0.147)\end{array}$ & $\begin{array}{r}0.534 \\
(0.082)\end{array}$ \\
\hline
\end{tabular}

Standard errors are in parentheses. 
Figure 1

New Graduates and Change in Employment

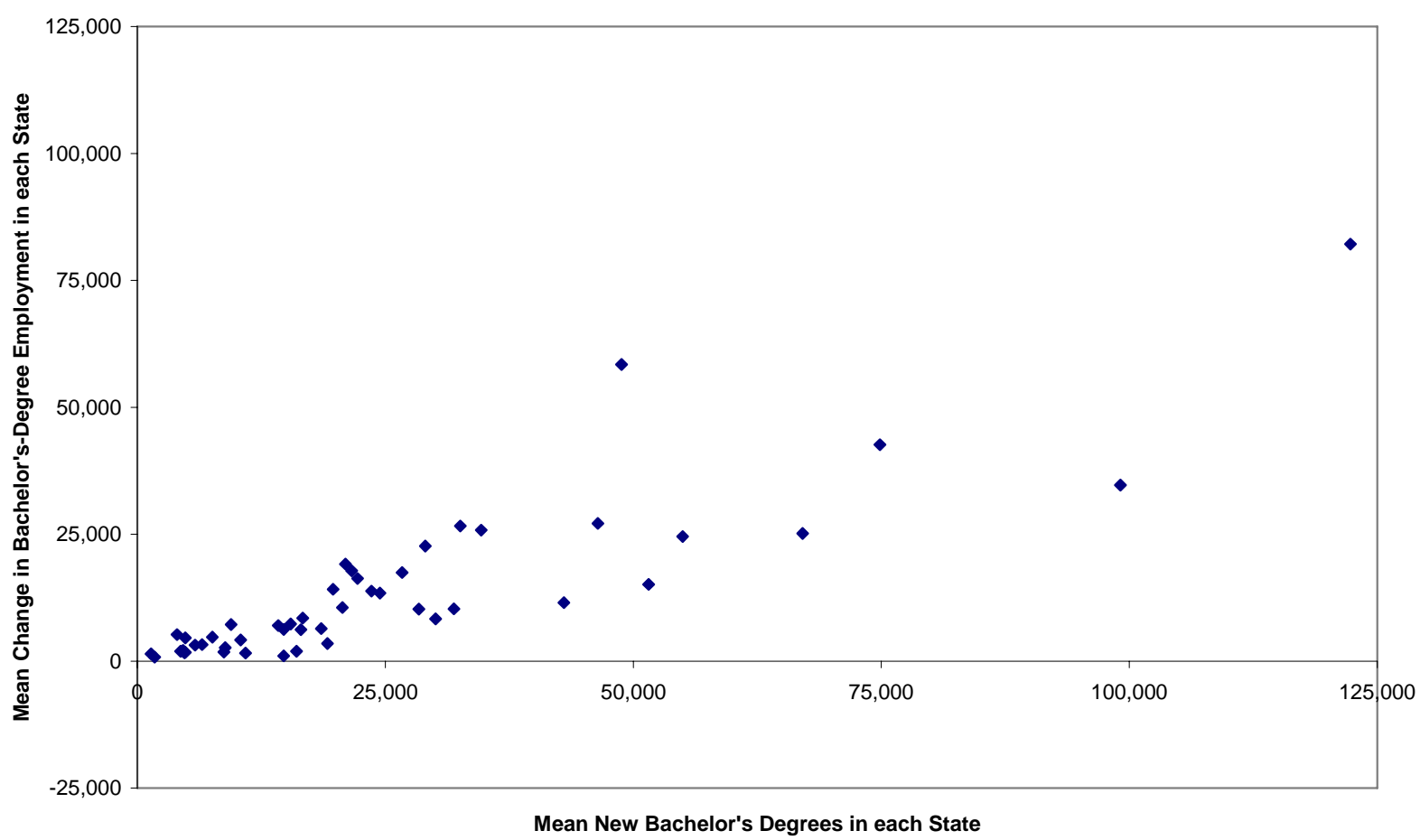


Working Paper Series

WP011: The Impact of New College Graduates on Intrastate Labor Markets

Download at: http://www.wiscape.wisc.edu/publications/WP011

Figure 2

New Graduates and Change in Unemployment

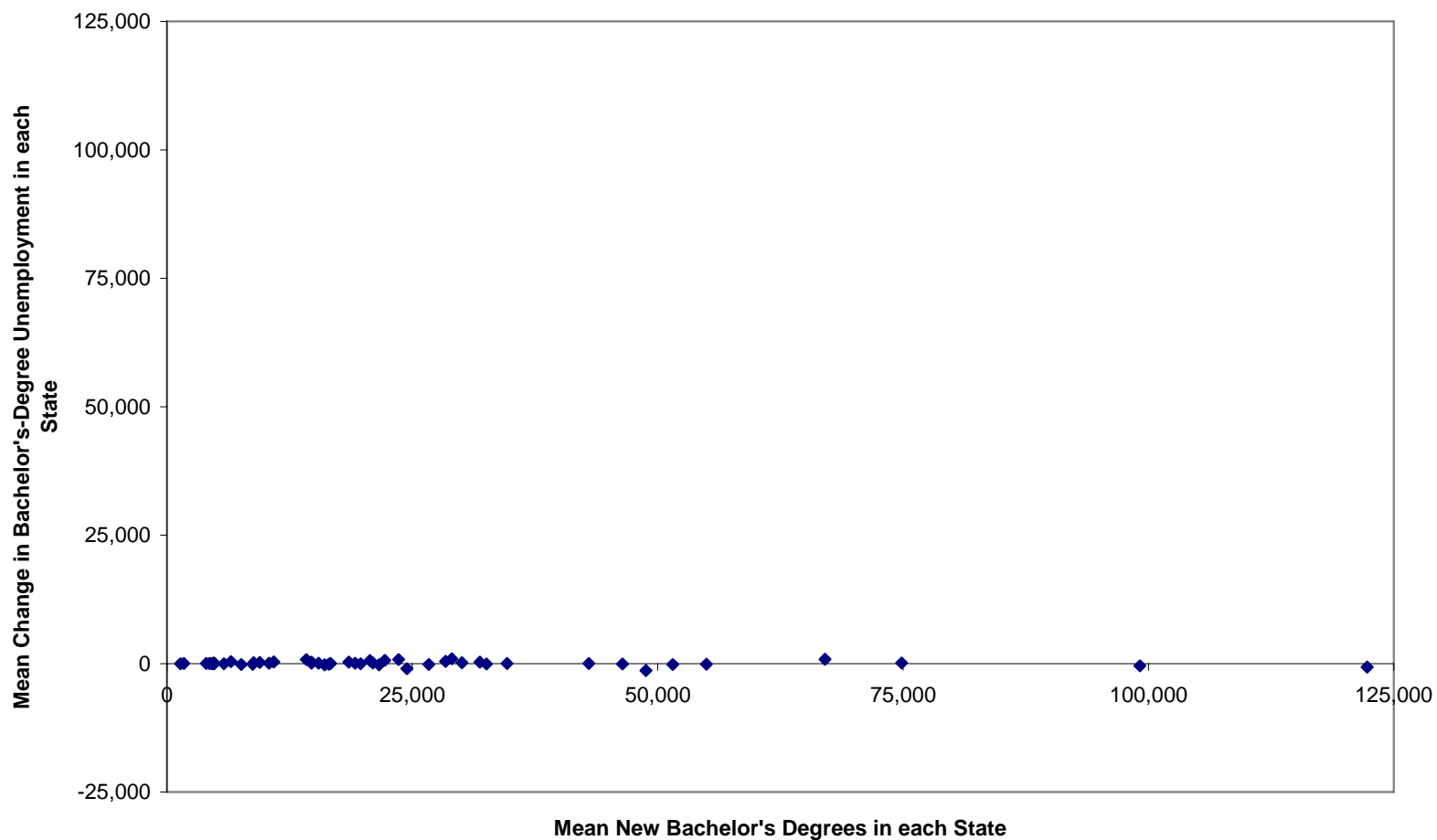


Working Paper Series

WP011: The Impact of New College Graduates on Intrastate Labor Markets

Download at: http://www.wiscape.wisc.edu/publications/WP011

Figure 3

New Graduates and Change in Nonparticipation

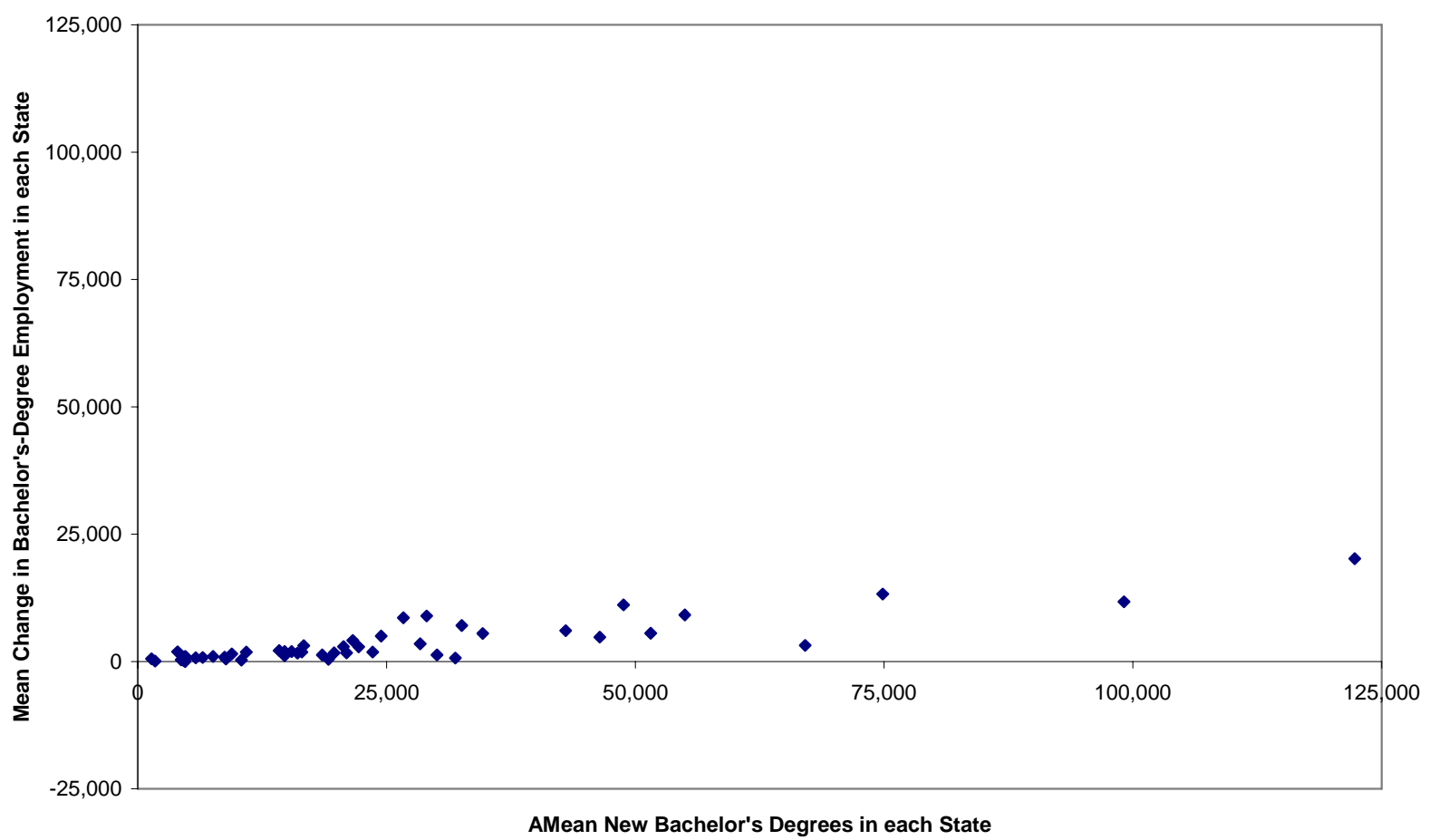


Figure 4

New Graduates and Net Out-Migration

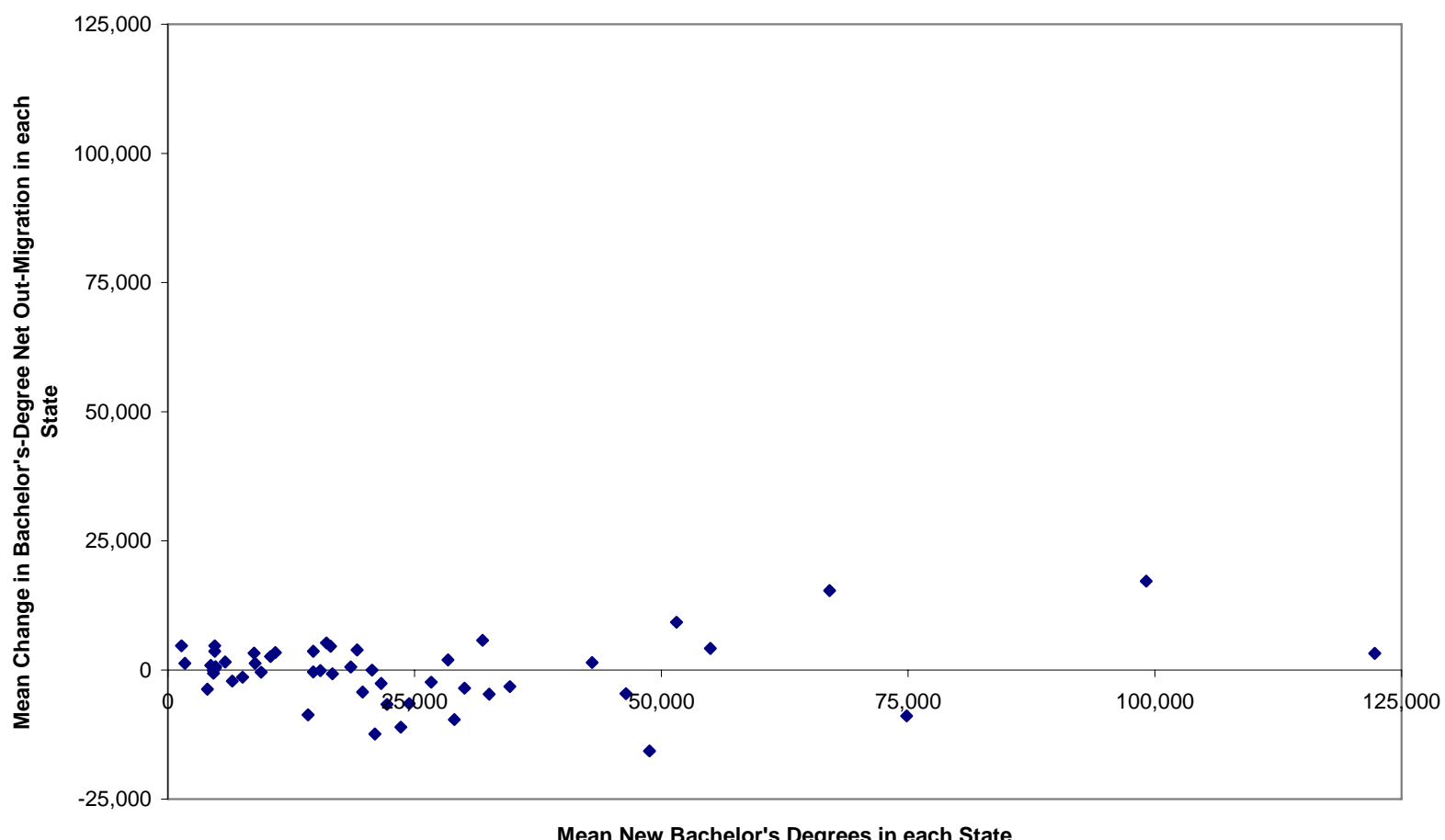


Figure 5

Flow Rate of New Graduates and Change in $\ln$ (Wages)

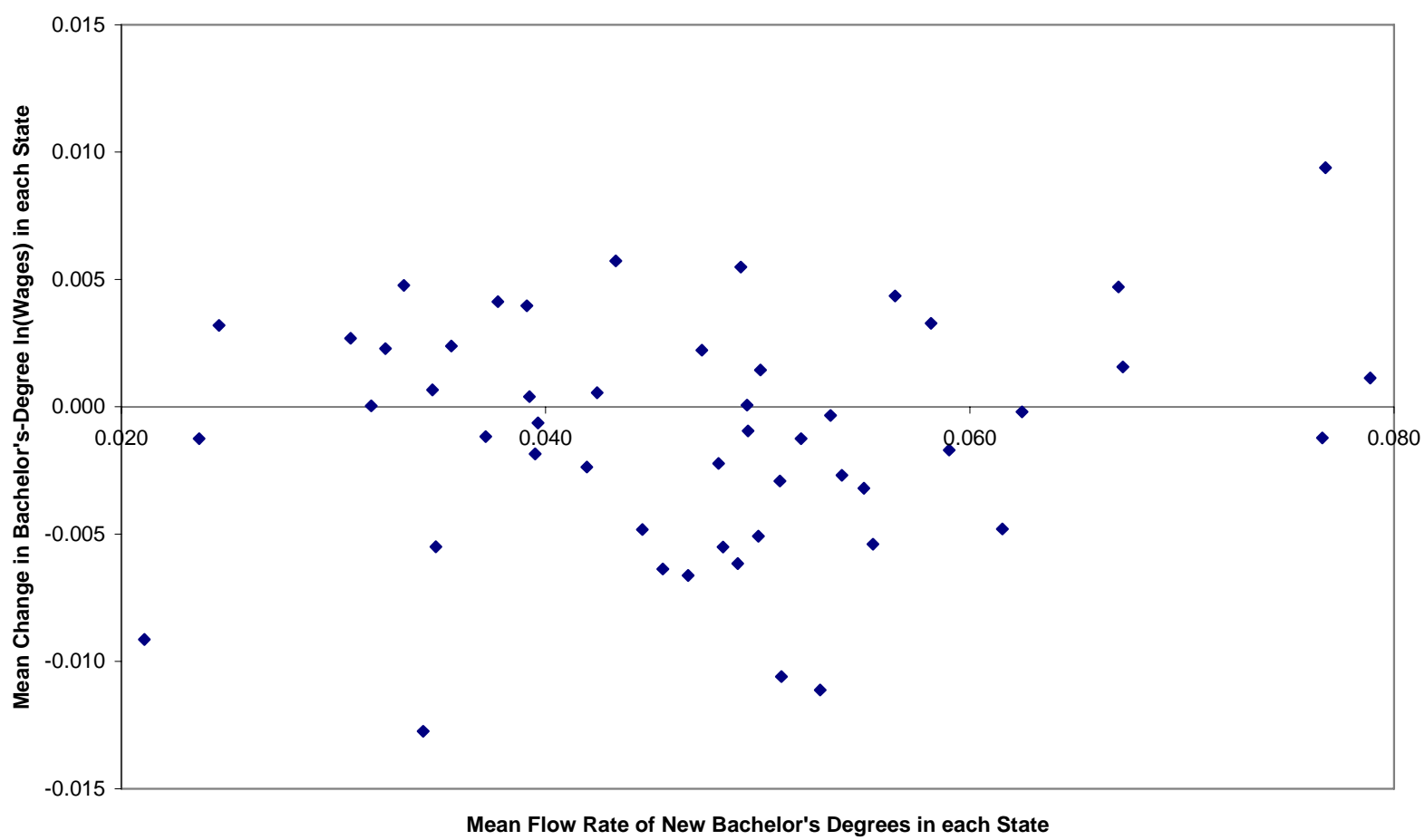




\section{Appendix Table 1}

Estimated Intrastate Labor-Market Impacts of New Bachelor's Degrees

Random Effects Model, Coefficients Unconstrained

\begin{tabular}{|c|c|c|c|c|}
\hline & \multicolumn{2}{|c|}{ OLS } & \multicolumn{2}{|c|}{ IV } \\
\hline & $\begin{array}{r}\text { All } \\
\text { Graduates }\end{array}$ & $\begin{array}{c}\text { Resident } \\
\text { Graduates }\end{array}$ & $\begin{array}{r}\text { All } \\
\text { Graduates }\end{array}$ & $\begin{array}{l}\text { Resident } \\
\text { Graduates }\end{array}$ \\
\hline$\Delta$ Employment & $\begin{array}{l}0.537 \\
(0.044)\end{array}$ & $\begin{array}{l}0.580 \\
(0.052)\end{array}$ & $\begin{array}{l}0.561 \\
(0.045)\end{array}$ & $\begin{array}{l}0.609 \\
(0.053)\end{array}$ \\
\hline$\Delta$ Unemployment & $\begin{array}{r}-0.006 \\
(0.010)\end{array}$ & $\begin{array}{l}-0.001 \\
(0.012)\end{array}$ & $\begin{array}{l}-0.007 \\
(0.010)\end{array}$ & $\begin{array}{r}-0.003 \\
(0.013)\end{array}$ \\
\hline$\Delta$ Nonparticipation & $\begin{array}{l}0.136 \\
(0.023)\end{array}$ & $\begin{array}{l}0.158 \\
(0.029)\end{array}$ & $\begin{array}{l}0.143 \\
(0.024)\end{array}$ & $\begin{array}{l}0.168 \\
(0.030)\end{array}$ \\
\hline Net Out-Migration & $\begin{array}{l}0.033 \\
(0.034)\end{array}$ & $\begin{array}{r}-0.001 \\
(0.038)\end{array}$ & $\begin{array}{l}0.008 \\
(0.035)\end{array}$ & $\begin{array}{l}-0.025 \\
(0.039)\end{array}$ \\
\hline$\Delta$ Attainment & $\begin{array}{l}0.667 \\
(0.052)\end{array}$ & $\begin{array}{r}0.736 \\
(0.063)\end{array}$ & $\begin{array}{l}0.697 \\
(0.053)\end{array}$ & $\begin{array}{l}0.775 \\
(0.065)\end{array}$ \\
\hline$\Delta \ln ($ Wages $)$ & $\begin{array}{r}-0.004 \\
(0.109)\end{array}$ & $\begin{array}{r}-0.003 \\
(0.133)\end{array}$ & $\begin{array}{l}-0.128 \\
(0.220)\end{array}$ & $\begin{array}{r}-0.025 \\
(0.270)\end{array}$ \\
\hline Out-Migration & $\begin{array}{l}0.618 \\
(0.031)\end{array}$ & $\begin{array}{l}0.627 \\
(0.033)\end{array}$ & $\begin{array}{l}0.641 \\
(0.032)\end{array}$ & $\begin{array}{l}0.665 \\
(0.034)\end{array}$ \\
\hline In-Migration & $\begin{array}{r}0.543 \\
(0.053)\end{array}$ & $\begin{array}{l}0.541 \\
(0.058)\end{array}$ & $\begin{array}{l}0.623 \\
(0.058)\end{array}$ & $\begin{array}{l}0.655 \\
(0.062)\end{array}$ \\
\hline Observations & 700 & 550 & 700 & 550 \\
\hline
\end{tabular}

Standard errors are in parentheses. 


\section{Appendix Table 2}

Estimated Intrastate Labor-Market Impacts of All New Public and Private Bachelor's Degrees OLS, Coefficients Constrained

\begin{tabular}{|c|c|c|c|c|}
\hline & Public & Private & Out-of-State & Northeast \\
\hline \multirow[t]{2}{*}{$\Delta$ Employment } & 0.876 & 0.274 & 0.536 & -0.098 \\
\hline & $(0.076)$ & $(0.206)$ & $(0.254)$ & $(0.074)$ \\
\hline \multirow[t]{2}{*}{$\Delta$ Unemployment } & 0.003 & 0.085 & -0.169 & 0.004 \\
\hline & $(0.033)$ & $(0.089)$ & $(0.110)$ & $(0.032)$ \\
\hline \multirow[t]{2}{*}{$\Delta$ Nonparticipation } & 0.186 & 0.264 & 0.006 & -0.036 \\
\hline & $(0.060)$ & $(0.163)$ & $(0.201)$ & $(0.059)$ \\
\hline \multirow[t]{2}{*}{ Net Out-Migration } & -0.065 & 0.378 & -0.373 & 0.131 \\
\hline & $(0.057)$ & $(0.154)$ & $(0.190)$ & $(0.056)$ \\
\hline \multirow[t]{2}{*}{$\Delta$ Attainment } & 1.065 & 0.622 & 0.373 & -0.131 \\
\hline & $(0.057)$ & $(0.154)$ & $(0.190)$ & $(0.056)$ \\
\hline \multirow[t]{2}{*}{$\Delta \ln ($ Wages $)$} & -0.035 & 0.050 & 0.028 & -0.056 \\
\hline & $(0.185)$ & $(0.264)$ & $(0.295)$ & $(0.124)$ \\
\hline \multirow[t]{2}{*}{ Out-Migration } & 0.649 & 0.459 & 0.599 & -0.119 \\
\hline & $(0.046)$ & $(0.125)$ & $(0.154)$ & $(0.045)$ \\
\hline \multirow[t]{2}{*}{ In-Migration } & 0.721 & 0.235 & 0.845 & -0.264 \\
\hline & $(0.060)$ & $(0.163)$ & $(0.201)$ & $(0.059)$ \\
\hline
\end{tabular}

Standard errors are in parentheses. The coefficients on out-of-state and Northeast the differences in the effects of these graduates from the effects of all graduates. 
Wisconsin Center for the Advancement of Postsecondary Education (WISCAPE)

University of Wisconsin-Madison

409 Education Building

1000 Bascom Hill

Madison, WI 5706-1398

Phone: 608-265-6342

Fax: 608-262-4881

E-mail: wiscape-info@education.wisc.edu

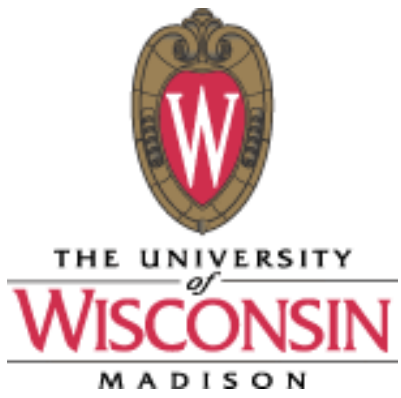

